\title{
Advances in 3D Printing for Tissue Engineering
}

\author{
Angelika Zaszczyńska (1), Maryla Moczulska-Heljak, Arkadiusz Gradys and Paweł Sajkiewicz *(1)
}

Institute of Fundamental Technological Research, Polish Academy of Sciences, Pawinskiego 5b St., 02-106 Warsaw, Poland; azasz@ippt.pan.pl (A.Z.); mheljak@ippt.pan.pl (M.M.-H.); argrad@ippt.pan.pl (A.G.)

* Correspondence: psajk@ippt.pan.pl

Citation: Zaszczyńska, A.; Moczulska-Heljak, M.; Gradys, A.; Sajkiewicz, P. Advances in 3D Printing for Tissue Engineering. Materials 2021, 14, 3149. https:// doi.org/10.3390/ma14123149

Academic Editor: Brunella Grigolo

Received: 15 May 2021

Accepted: 4 June 2021

Published: 8 June 2021

Publisher's Note: MDPI stays neutral with regard to jurisdictional claims in published maps and institutional affiliations.

Copyright: (c) 2021 by the authors. Licensee MDPI, Basel, Switzerland. This article is an open access article distributed under the terms and conditions of the Creative Commons Attribution (CC BY) license (https:// creativecommons.org/licenses/by/ $4.0 /)$.

\begin{abstract}
Tissue engineering (TE) scaffolds have enormous significance for the possibility of regeneration of complex tissue structures or even whole organs. Three-dimensional (3D) printing techniques allow fabricating TE scaffolds, having an extremely complex structure, in a repeatable and precise manner. Moreover, they enable the easy application of computer-assisted methods to TE scaffold design. The latest additive manufacturing techniques open up opportunities not otherwise available. This study aimed to summarize the state-of-art field of 3D printing techniques in applications for tissue engineering with a focus on the latest advancements. The following topics are discussed: systematics of the available 3D printing techniques applied for TE scaffold fabrication; overview of $3 \mathrm{D}$ printable biomaterials and advancements in 3D-printing-assisted tissue engineering.
\end{abstract}

Keywords: tissue engineering; 3D printing; biomaterials

\section{Introduction}

Recent progress in the 3D printing method stems from the regenerative ability of the human body. It was reported that there were about 31 million Americans who suffered from body defects [1]. Every year, there is globally an increasing number of patients suffering from various types of body defects caused by injuries and degenerative processes of various origin [2,3]. Critical defects require support for the growth of the cells [4]. Native regeneration of the human body is limited by multiple elements such as availability of the growth hormones or by functionality of the defected tissue. For many years, the standard medical treatment in such cases has been autologous transplantation (less frequently, allologous) or implantation of an endoprosthesis imitating the lost organ. The abovementioned methods allow to restore the full or partial function of the lost organ (tissue defect); however, it should be noted that they are characterized by many disadvantages affecting the comfort of the patient's life. Hence, the idea of developing methods supporting the full regeneration of tissue defects was born, which are based on laboratory cell cultures collectively referred to as tissue engineering (TE).

Tissue engineering belongs to a group of relatively new fields of human activity. It combines elements of biology, medicine, material engineering, and mechanics. The basic aim of tissue engineering is to develop methods supporting the regeneration of damaged tissues and organs, especially those so far considered to be non-regenerative. Examples of such tissue and organ damage are provided by everyday clinical practice. These are usually critical defects of bone, skin, or nerve tissue. The most common cause of such defects is various types of trauma, with the second most common being those resulting directly from tumor activity or those resulting from resection of tumor sites. Typically, the regenerated tissue (cell culture) is initially cultured in vitro (in a bioreactor), and then the partially regenerated tissue is implanted in situ at the site of the defect. To ensure an even distribution of the cells in the defect space, so-called TE scaffolds are used, which are porous structures that provide an appropriate substrate for the cultured cells and, at the same time, allow free access to nutrients and drainage of cell metabolism products. An equally important task of tissue scaffolds is to take over the mechanical function of the damaged 
tissue (organ). For this reason, they should be characterized by appropriate stiffness. It is also expected that the implanted scaffold will be fully resorbed by the time the tissue defect is fully regenerated. To meet this requirement, scaffolds are most often fabricated from biodegradable polymers, either natural, such as chitosan or cellulose, or synthetic (polycaprolactone (PCL), polylactide (PLA), etc.). It is not uncommon to use ceramic materials ( $\beta$-TCP, hydroxyapatite) in a polymeric matrix to improve the biocompatibility of the material used. The designed TE scaffolds must meet many different requirements (in practice, often contradictory). It also turns out that how the scaffold performs its function is determined by factors of various nature, ranging from purely biological to mechanical.

There are numerous methods of TE scaffolds' fabrication. Amongst them, one can mention a few conventional methods, such as the solvent casting method, phase separation, or electrospinning, which enable limited control over the scaffold geometry. Additionally, they are characterized by poor repeatability. The above limitations do not apply to the additive manufacturing (AM) methods, commonly known as 3D printing methods. Additionally, 3D printing methods enable easy application of computer-assisted methods of TE scaffold design. Presently, there are a multitude of 3D printing techniques applied for TE purposes. They enable fabrication of TE scaffolds made of different types of materials including polyesters, ceramics, metals, or hydrogels.

Generally, an incredible advantage of 3D printing is the possibility of the fabrication of complex structures, unprofitable to manufacture using injection molding methods [5]. Furthermore, 3D printers have been improved for extremely high resolution, which fosters their use in tissue engineering. There are documented attempts of the adaptation of industrial printers to make them usable for printing scaffolds for tissue engineering. Nowadays, 3D printing methods enable fabrication of TE constructs used for the regeneration of different types of tissues, such as skin [6], cartilage [7], and vascular networks [8], as well as whole organs [9].

This review summarizes limitations and general principles of the most extensively used additive manufacturing technologies, including extrusion-based as well as jetting systems. Thus, current methods of printing and printable materials will be discussed. Additionally, the article highlights advanced scaffold fabrication methods for tissue engineering applications.

\section{Scaffolds for Tissue Engineering}

Daily, by average, 13 people die due to a long waiting time for organ transplantation [10]. There exists also a problematic issue related to tissue compatibility. In such a situation, tissue engineering may offer various unique methods of scaffold formation, where the tissue compatibility issue may be easily overcome. The idea and the goal is to deliver a functional compatible organ using the patient's own cells. However, such a process may be a highly complex task as there exist numerous factors related to the organism's physiology, such as culturing many cell types [11]. In general, scaffolds are essential for the creation of graft structures. TE scaffolds are a substratum for cells' migration/differentiation and the creation of new regenerated tissue. Thus, properties of the materials, especially chemical and physical, as well as the architecture and morphology, are crucial for cell proliferation and viability $[12,13]$. Moreover, successful repair of the defects sometimes requires reconstruction of different types of coexisting tissues, such as bones, glands, muscles, vessels, ligaments, nerves, and cartilage. The scaffolds' morphology and architecture are crucial at various levels: macro, micro, and nano. At the macro level, the architecture is related to the scaffold size and shape from the perspective of the size and shape of the defect, which are essential for the contact and interactions between the scaffold and the native tissues, matrix-cell interactions, and nutrients' transport [14]. At the micro level, it is characterized by scaffold porosity, pore shape, or pore spatial distribution, each of which is responsible for general scaffold permeability. At the nano level, the morphology is related to the fiber surface characteristics, which are supposed to be responsible for cells' differentiation and proliferation [15]. 
The most critical factors in 3D printing scaffolds are the type of fabrication method and the choice of a biomaterial. Biomaterials interact with biological systems and can be classified by various criteria such as biodegradability, physical and chemical composition, or the application of certain modifications [16]. The choice of a biomaterial is connected with the character of the damaged tissue. Favored materials are usually biodegradable and piezoelectric biomaterials. The main groups of these materials consist of polymers (synthetic and natural), ceramics, and composites. Ceramic scaffolds are preferred in orthodontic applications; composite scaffolds have applications in dental tissue engineering, whereas polymers are used in soft tissue engineering [17].

\subsection{Different TE Strategies}

Generally, two distinct strategies are used in TE to treat tissue defects using tissue scaffolds [18]. In each, the fabricated scaffold is seeded with cells (sometimes cells are embedded in a scaffold matrix), followed by cell culture in a bioreactor, after which the scaffold filled with the newly formed tissue is implanted into the defect site. The difference lies in the choice of the moment of implantation. In the first of the strategies, fully matured and remodeled tissue is implanted in the defect site. In this case, the scaffold should be completely degraded and metabolized before the moment of implantation. In the second strategy, a scaffold filled with not fully matured tissue is implanted. Depending on the strategy chosen, the implanted scaffold should be characterized by different degradation (erosion) kinetics.

TE scaffolds' fabrication is followed usually by adequate surface modifications in order to achieve the desired structure/properties from the cells' perspective. Various hormones or growth factors are usually added during the cell culture. Figure 1 shows the process of creating the tissue engineering product.

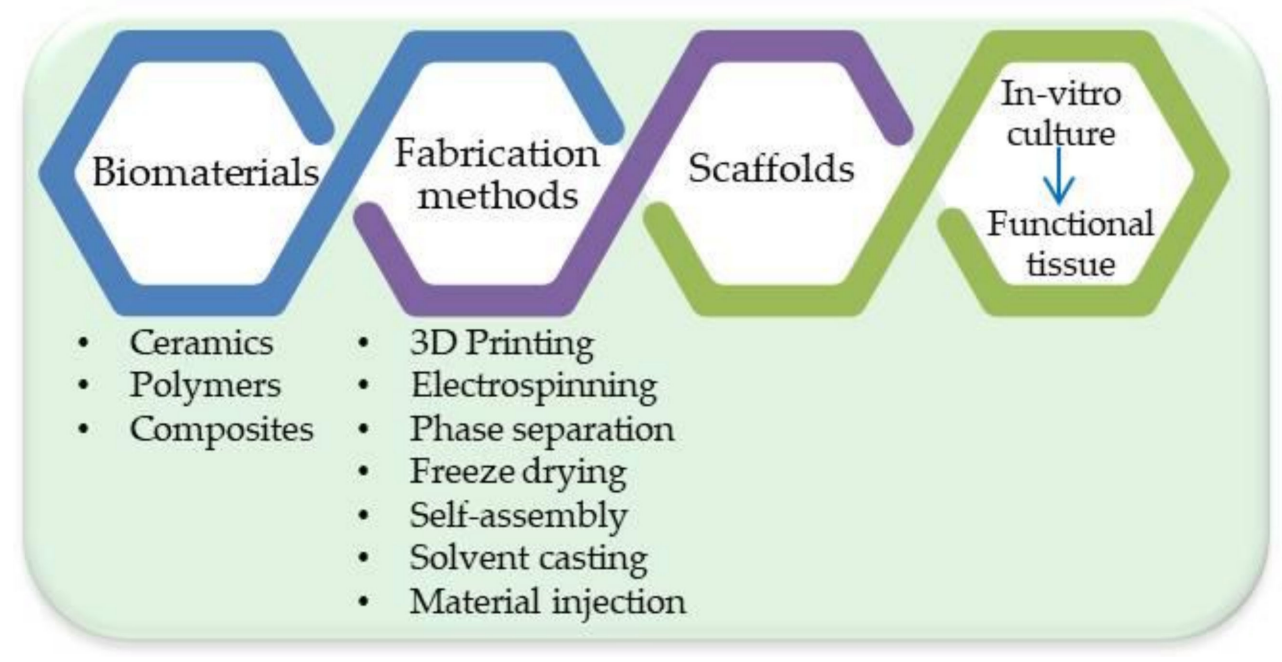

Figure 1. Tissue Engineering process.

\subsection{Conventional TE Scaffold Fabrication Techniques vs. 3D Printing Techniques}

There are various methods of scaffold formation allowing them to meet the requirements in various specific applications. In addition, many biomaterials are constantly improved for more effective use in tissue engineering. A schematic illustration is shown in Figure 2. 


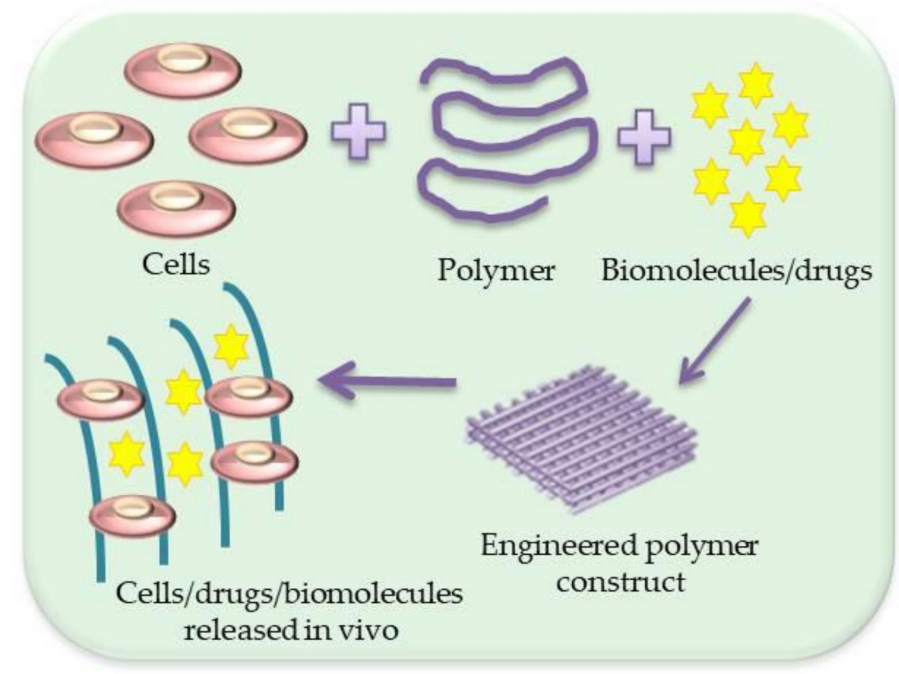

Figure 2. Schematic illustration of scaffold with cells/drugs or biomolecules' formation.

The mostly used scaffold fabrication methods include: electrospinning, additive manufacturing, phase separation, solution casting, foaming, extrusion, and self assembly [19]. In order to limit some disadvantages of the methods, a combination of them is often used, which sometimes leads to very interesting and promising effects [20]. Figure 3 shows various techniques to fabricate three-dimensional scaffolds while some of them are described further.

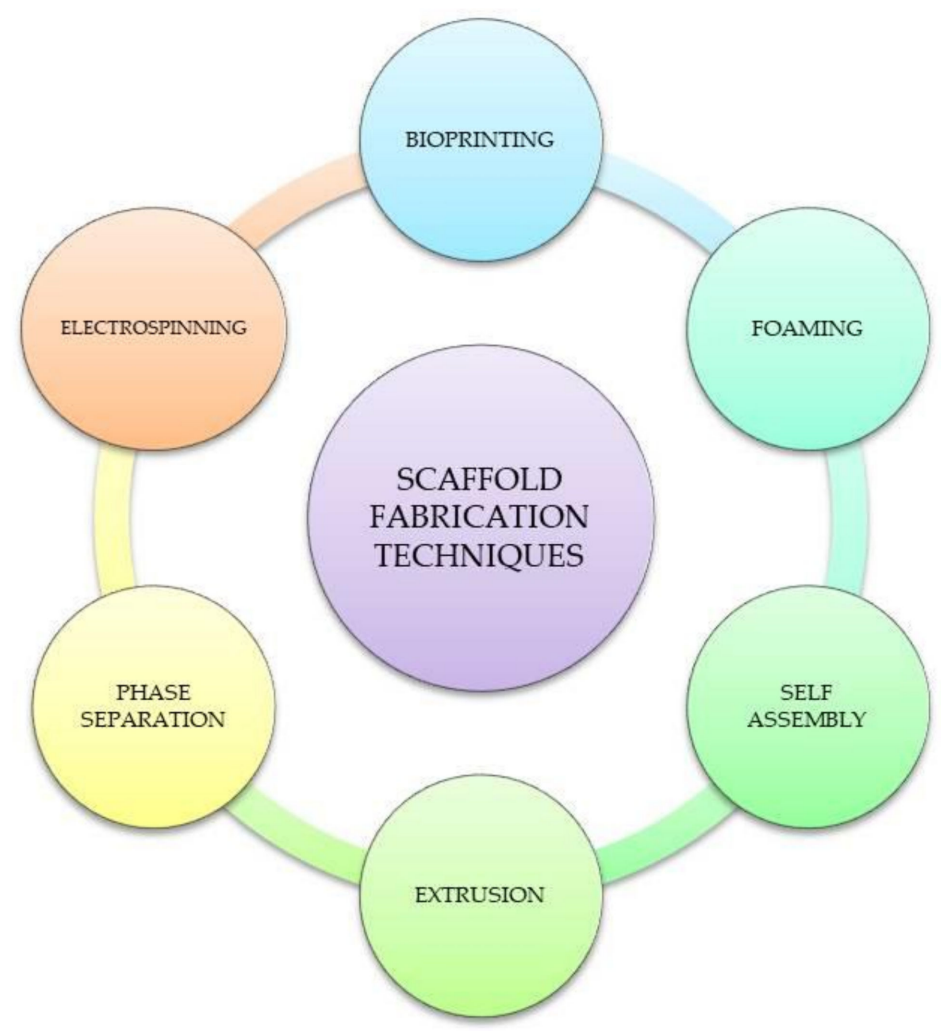

Figure 3. Scaffolds' fabrication techniques.

One of the most popular processes for scaffold formation is the electrospinning technique (Figure 4). The spinneret filled with electroconductive polymer, usually a solution, is connected to a high electric potential (several to tens $\mathrm{kV}$ ) at low current. The polymer is spun in the form of fibers, while solvent is evaporating on the way between a spinneret and a collector. A collector is electrically grounded or at a low counter potential and may be sta- 
tionary or rotating. The resulting scaffold consists of a micron, submicron, or nanofibrous architecture, either random or aligned, depending on the collector type and mode used. This method of scaffold fabrication allows the formation of fibrous nonwovens with morphology and architecture mimicking the fibrous structure of the extracellular matrix (ECM) which is crucial from the perspective of cells. In this process, a large number of various polymers and solvents can be used, both natural, such as gelatin, chitosan, collagen, etc., and synthetic, such as polycaprolactone (PCL) [21], polyvinylidene fluoride (PVDF) [22], poly(3-hydroxybutyrate-co-3-hydroxyvalerate) (PHBV) [23], poly(methyl methacrylate) (PMMA) [24], etc. By connecting different types of materials, hybrid materials can be developed, particularly as a mixture of synthetic and natural polymers. Although electrospinning is a relatively simple process from the instrumental perspective, it is quite complex when analyzing physical phenomena on the process between the moment of jet formation and collection of fibers on the collector. The electrostatic field between the liquid and collector results in a cone-shaped polymer solution to flow out (s.c. Taylor cone). Then, the polymer jet is ejected from the Taylor cone when the electric field exceeds the polymer liquid's surface tension, followed by various instabilities including bending instability of the jet due to repulsion of the electric charges on the jet surface. By modifying some parameters of the electrospinning process, of the materials, and of external conditions, such as the solution flow rate, spinneret-collector distance, the rotational speed of the collector, voltage, polymer concentration, polymer molecular weight, humidity, and temperature, the morphology and architecture of the scaffold can be dramatically changed according to the desired application [25].

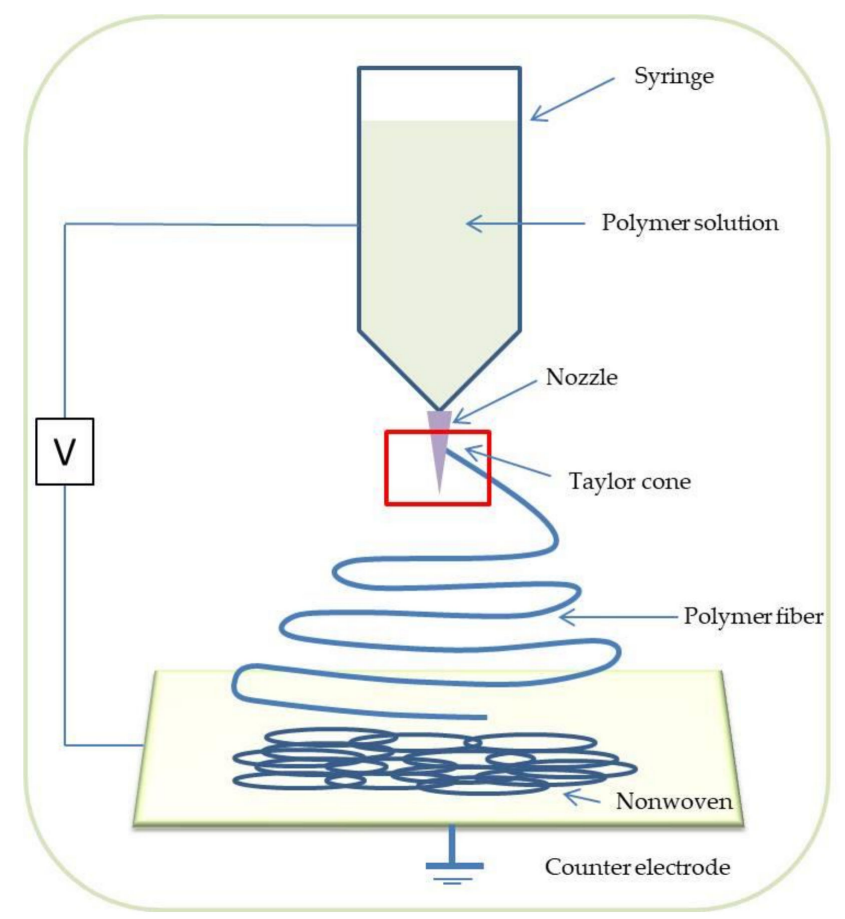

Figure 4. Scheme illustration of electrospinning technique.

Phase separation is another traditional method to produce complex and high-porosity three-dimensional scaffolds. There are various modifications of this method, which are generally based on two processes, namely, liquid-solid and liquid-liquid phase separation. They are technically implemented by using either thermally or non-solvent-induced processes. In the first case, separation is obtained by reducing polymer solubility through a change in the solution temperature resulting in polymer precipitation. In the second case, phase separation is obtained by immersion of a polymer solution in a non-solvent (for the polymer) bath in order to leach away the polymer solvent (wet phase inversion method). There are additional techniques of porous scaffolds' formation by phase sep- 
aration techniques based on highly compressed gases or supercritical fluids. The phase separation method has been developed and improved over the years and used as a manufacturing method to form porous polymer membranes. The resulting morphology of phase-separated scaffolds is extremely sensitive to the process parameters, so desired parameters of three-dimensional scaffolds can be achieved by adjusting various process and materials' parameters [26].

Mixing an organic solvent with polymers, adding granules or spheres as porogens, and casting this solution to the mold, followed by the extraction of porogens, is known as the solvent casting/particulate leaching method (SCPL). It is possible to control the final pore size by the size, content, and distribution of porogens. The solvent evaporates, and the porogen is removed by dissolving, leaving behind a porous structure. Solvent scaffolds can be used, for instance, for cardiac tissue engineering applications due to the uniform distribution of endothelial cells [27]. This technique allows preparation of structures with regular porosity, but with a quite limited thickness. A summary of these methods is given in Table 1.

Table 1. Selected scaffolds' formation techniques—main applications and advantages/disadvantages.

\begin{tabular}{|c|c|c|c|}
\hline Method & Applications & Advantages & Disadvantages \\
\hline Electrospinning & $\begin{array}{l}\text { Bone, nerve, skin, and cardiac } \\
\text { tissue engineering [28] }\end{array}$ & $\begin{array}{l}\text { High surface area to volume ratio, } \\
\text { high porosity, easy process }\end{array}$ & Limited range of polymers \\
\hline Phase separation & $\begin{array}{l}\text { Protein delivery applications } \\
\text { and/or drug release [29] }\end{array}$ & $\begin{array}{l}\text { Bioactive agents can be } \\
\text { incorporated into the structure, } \\
\text { high porosity }\end{array}$ & $\begin{array}{l}\text { Limited ranges of pore size, } \\
\text { problems with residual solvents }\end{array}$ \\
\hline Solvent casting & $\begin{array}{l}\text { Vascular tissue engineering } \\
\text { applications [30] }\end{array}$ & Simple method, controlled porosity & $\begin{array}{l}\text { Low mechanical strength, limited } \\
\text { thickness, small pore size }\end{array}$ \\
\hline
\end{tabular}

Tissue engineering requires fundamental systemic understanding of the human organism including cellular differentiation and proliferation [31-34]. To summarize, the prerequisites of TE scaffolds (not only those 3D printed) are extremely challenging and manifold. They include: he material for TE scaffold fabrication should be biocompatible (that is, scaffolds cannot cause any cytotoxicity or immune response); scaffolds should be easy to sterilize to prevent infections. Moreover, mechanical properties should be enough for patients' regular life and activity [18].

\section{3D Printing of Tissue Engineering Scaffolds}

\subsection{Overall Characteristics of 3D Printing Techniques}

Since the emergence of the concept of using tissue engineering products in reconstructive medicine, many methods of producing TE scaffolds have been developed, starting from the simplest ones, such as the method of sugar- or salt-crystal-leaching from a solid structure, to the most advanced ones, which include rapid prototyping (RP) and rapid manufacturing (RM) methods. The methods of rapid manufacturing are currently a very dynamically developing field. Practically on an ongoing basis, modifications are made to existing methods; new methods and devices are created, and the RM industry is now created both by scientific institutions and commercial manufacturers of hardware and software. Unfortunately, the dynamism of industry development makes it difficult to systematize existing methods. Many of the common names of RM methods are registered trademarks, which means that often even several manufacturers produce very similar devices using different names for virtually the same manufacturing method used by the devices. These names come into common use at the same time, which creates a lot of confusion. One needs to be aware of the fact that terms such as additive manufacturing, rapid prototyping/manufacturing, solid free-form fabrication, as well as 3D printing, are essentially synonymous. In the remainder of this paper, we have chosen to use the term 3D printing. It is a relatively new method of the fabrication of TE scaffolds with controlled architecture. Despite the fact that there are many various 3D printing techniques, including 
stereolithography, bioprinting, inkjet printing, fused deposition modelling (FDM), PED (Precision Extruding Deposition), laser beam melting, polyjet, electron beam melting, digital laser printing (DLP), and selective laser sintering (SLS) [35], the common feature of all mentioned methods is the general principle of material deposition layer-by-layer until the final product is created [36].

Thus, the 3D TE scaffold is fabricated by the successive addition of consecutive 2D layers of a material. Additive manufacturing has numerous advantages, such as the ability to create complex structures and the possibility of the application of the Computer-Aided Design (CAD) methods. It enables the use of various types of biomaterials [37]. Using living cells and biodegradable polymers allows for the development of methods and novel strategies to create complex tissues and, possibly in the future, whole organs [38]. A 3D-printed TE scaffold can be designed using patient-specific data. The CAD method allows for the precise designing of the 3D organ or its missing part. Selected features of living organs, such as porosity or vasculature, may be taken into account in the CAD 3D model. Due to these remarkable advantages, 3D printing is gaining significant interest in regenerative medicine and tissue engineering [39].

In 3D printing, techniques may be distinguished into two categories-binder 3D printing and direct $3 \mathrm{D}$ printing.

The former is also called the "drop on powder technique" (Figure 5) [40]. Objects are made by an inkjet liquid printing binder solution on a powder base [41-43]. The process starts by spreading the powder layer on the building platform. Positioning software prints the pattern using a deposition of droplets on the layer with powder. Next, the building platform, powder, and part are lowered, and the next layer can be applied. Then, the powder is removed, and one can observe the printed part. The disadvantages of the method include relatively low resolution and problems with printhead reliability. A small nozzle can have better quality but is more prone to clogging. As an advantage, the fabrication of complicated scaffolds with internal channels is feasible because the surrounding powder supports objects.

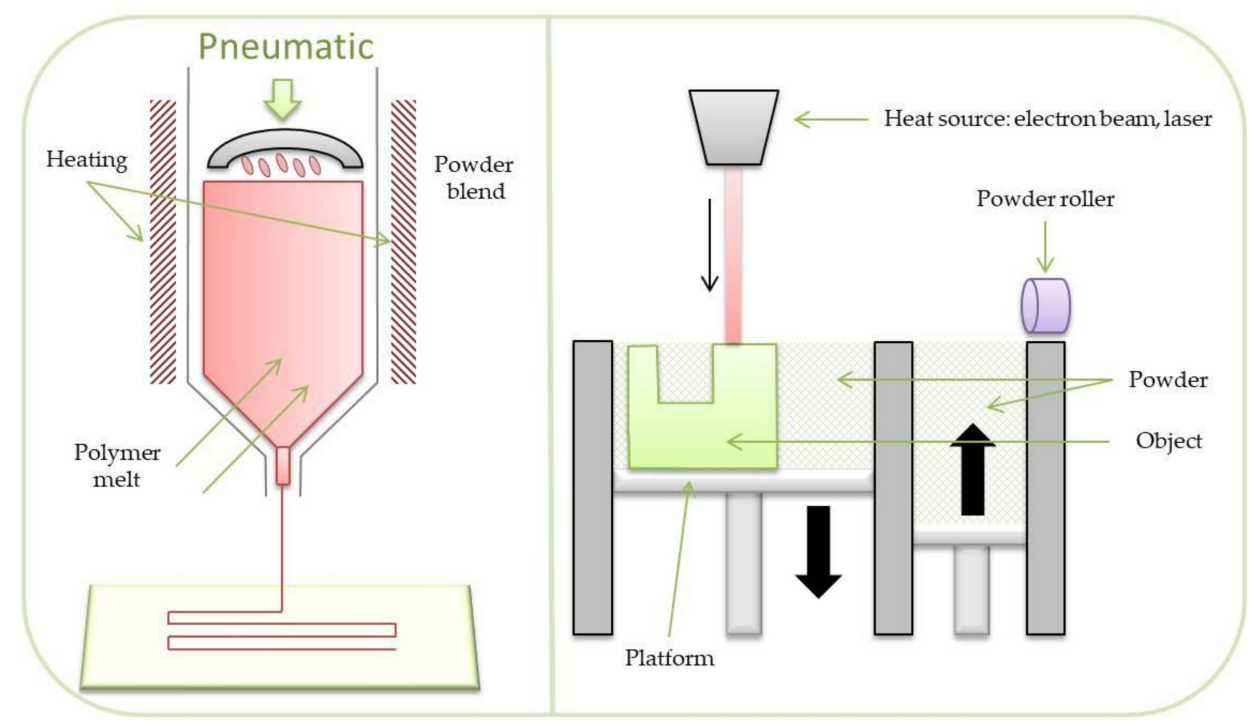

Figure 5. Scheme illustration of direct 3D printing technique (left) and "drop on powder technique" (right).

In the case of direct 3D printing, which is shown in Figure 5, the nozzle of a 3D printer moves back and forth dispensing waxes or plastic polymers, which solidify to form consecutive layers of the fabricated 3D object.

\subsection{D Printing Techniques Applicable to TE}

Below, the most-known 3D printing techniques, which are applicable to TE, are listed. 


\subsubsection{Bioprinting}

This method allows for the fabrication of soft 3D tissue scaffolds combining biomaterials, living cells, as well as growth factors. It enables the fabrication of biomedical parts that maximally imitate natural tissue characteristics. Generally, 3D bioprinting utilizes the layerby-layer deposition of materials known as bioinks to create tissue-like structures. There are four main categories of 3D bioprinting: inkjet bioprinting, laser-assisted bioprinting, extrusion bioprinting, and stereolithography [44].

\subsubsection{Inkjet Bioprinting}

In this type of bioprinting method, a mixture of living cells and a bioink is stored in a chamber joined with the printhead [45]. During the process, the piezoelectric transducer deforms the printhead. Spatially defined droplets establish tissue constructs (Figure 6). The main advantage of the method is its low cost and high cell viability [46]. Nevertheless, this method is limited by numerous problems, such as printhead clogging, uneven distribution of the cells, and inability to print viscous materials. Due to these problems, inkjet bioprinting has received less consideration by researchers in recent years [47].

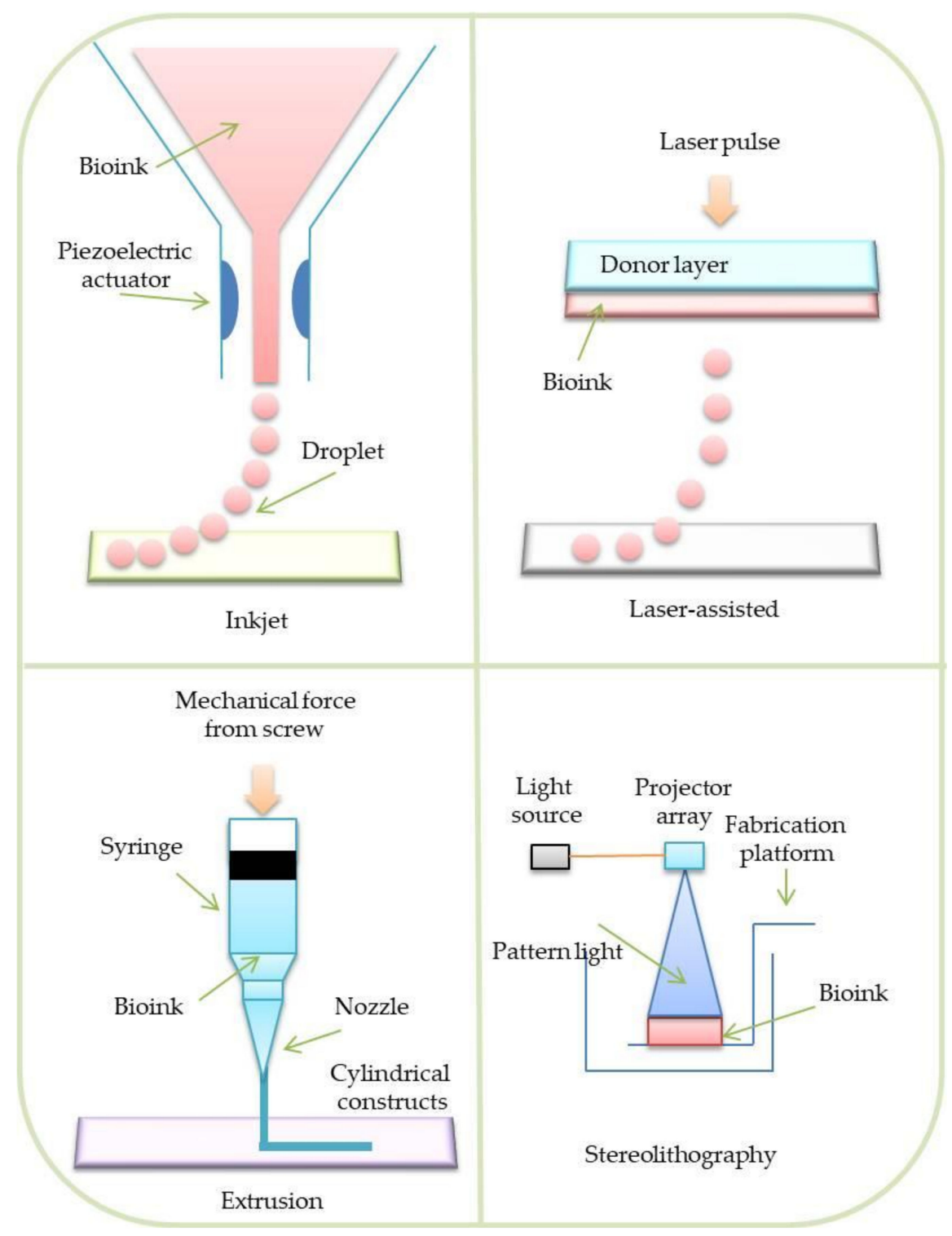

Figure 6. Four main categories of bioprinting. 


\subsubsection{Laser-Assisted Bioprinting}

Typical laser-assisted bioprinting (LAB) involves specialized layers, such as a bioink layer, an energy-absorbing layer, a donor (quartz/glass), and a collecting layer, to form structures [48]. During the process, a laser beam is focused on the energy-absorbing layer. Next, this layer vaporizes and creates an air bubble between the bioink and donor layers. The formation of a bubble ejects the desired amount of the bioink on the collecting layer. A tissue structure is created in a droplet-by-droplet manner (Figure 6) [49]. LAB is feasible for use with high cell density and viscous materials. Additionally, it has been reported that the method is characterized by high cell viability (95\%) and resolves the clogging issues. Nevertheless, LAB is an expensive process, which generates a very high cost with large-scale projects. Therefore, only a few printer prototypes were created. [50,51].

\subsubsection{Extrusion Bioprinting}

The extrusion bioprinting technique is based on liquid extrusion (paste, solution) from a pressurized syringe through a needle to a solution with controlled density. The materials are extruded in a form of long strands or dots to create complex structures [52]. The printing process can be conducted at room temperature and used to print natural biomaterials, especially hydrogels (Figure 6) [53].

\subsubsection{Stereolithography}

Stereolithography (SLA) is the first developed method of rapid prototyping expanded in the late 1980s [54]. Stereolithography rasters use a laser beam to control the polymerization process of bioinks in a 2D layer. After the deposition of each layer of a material, curing follows. During the curing process, a photosensitive hydrogel is subjected to UV or visible light. When a given layer is polymerized, the process is repeated, overlapping the previous layer, up to the moment when the whole scaffold is completed. This method allows the use of the following hydrogel materials (Figure 6) [55]: Polyethylene glycol diacrylate (PEGDA) and gelatin methacryloyl (GelMA) [56]; photo-initiators can be also added [57,58] The adjustment of various polymerization process parameters, including light energy and intensity, speed of printing, layer thickness, and exposure time, enables the achievement of a high-quality (including resolution) product [59-64]. Nevertheless, compared to the other methods, the SLA process is relatively time consuming, which makes the process feasible for small-detailed objects.

\subsection{Fused Deposition Modeling and the Other Microfiber Extrusion Methods}

In the fused deposition modelling (FDM) (Figure 7, left) technique, a coiled polymer filament is heated up and extruded through a nozzle on the platform. When the polymer contacts with the platform, it solidifies [65]. The main limitations of using FDM printers in TE include spatial resolution and possible thermal degradation of the polymeric material. FDM enables the use of thermoresponsive polymers such as polycaprolactone (PCL), polylactide (PLA), or polyglycolide (PGA). One of the criteria for selecting a material suitable for FDM is its high thermal stability, which many aliphatic polyesters, unfortunately, do not have. Thermal degradation of plastics is a particularly noticeable problem in the case of devices processing polymer granules (the original FDM method is less exposed to the negative effects of this phenomenon). The polymer heated for a long time loses its viscosity suitable for the proper course of the manufacturing process. In other 3D printing techniques belonging to the polymer microfiber extrusion group, the method of the material supplying may be different. In the case of the precision extruding deposition (PED), the material is supplied in the form of polymer granules, which are thermally plasticized and extruded under pressure through a nozzle. The described group of methods has been successfully used in the fabrication of TE scaffolds for many years. Thanks to the methods based on microfiber extrusion, tissue scaffolds with a strictly planned fibrous structure can be obtained. The disadvantages of the method include the fact that, due to a too-high 
polymer processing temperature, it is not possible to produce scaffolds with biomolecules or living cells incorporated into the fiber structure.

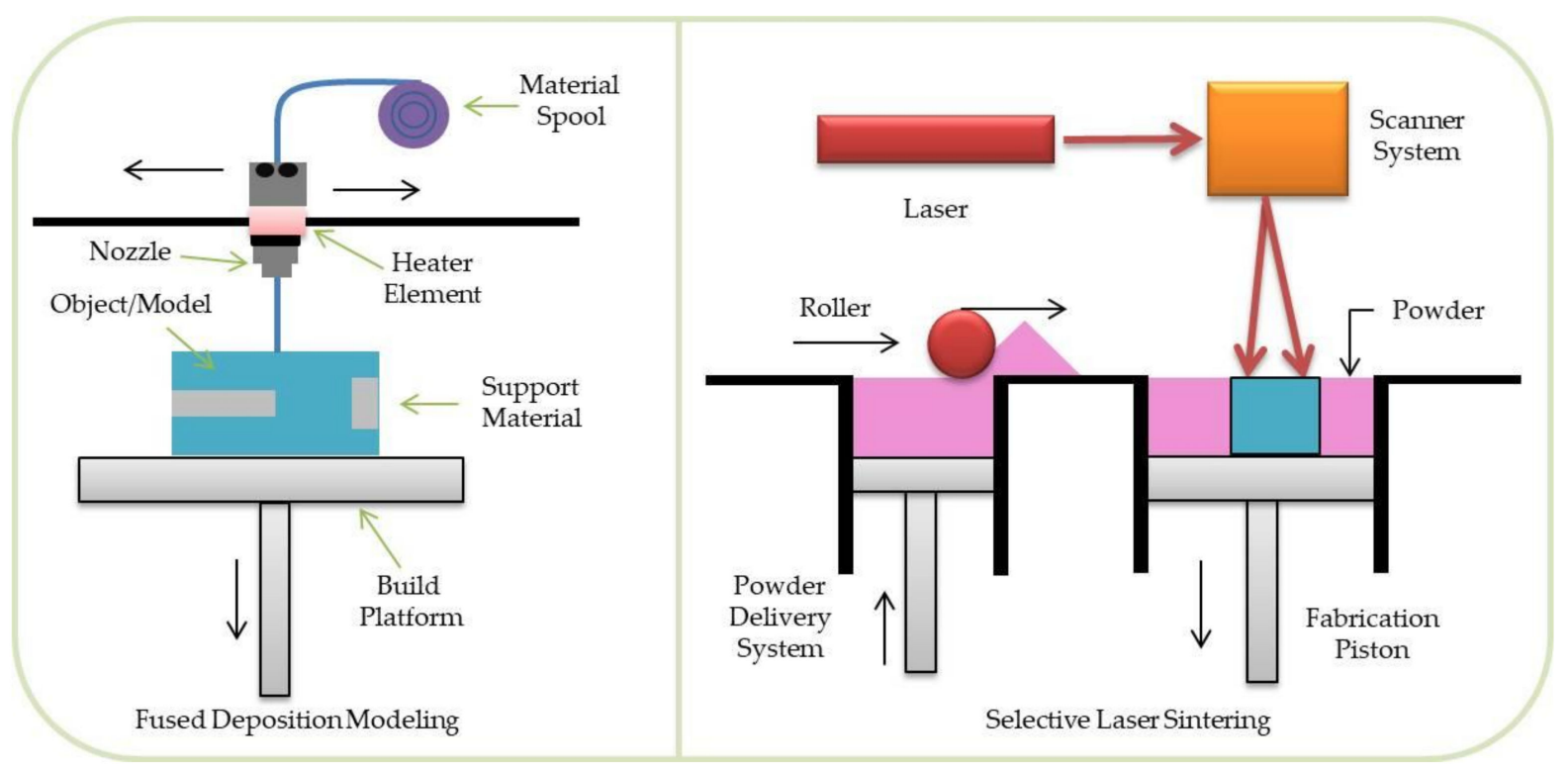

Figure 7. Scheme illustration of FDM (left) and SLS (right) process.

\subsection{Selective Laser Sintering}

In the method, the polymeric powder particles are heated up slightly above the polymer glass transition temperature by a laser beam [66]. This leads to partial melting of the particles [67], during which molecular diffusion on the particles' surface takes place, which leads to particles' fusion. After fabrication of each object layer, the building platform is lowered, a new layer of powder particles is spread on the top and connected with the previous layer (Figure 7, right).

\subsection{Melt-Spinning}

Melt electrospinning (MES) is a relatively new 3D TE scaffold fabrication technique, being the alternative to conventional solution electrospinning (SES) known for disadvantages related to toxic polymeric solutions [68]. Residues of solvents, e.g., chloroform, DMSO (dimethyl sulfoxide), DMF (dimethyloformamid), that can be used by SES may be harmful to living cells seeded on the scaffold. SES limitations were overcome by the use of the molten polymer instead of the polymer solution. To be jetted in an electric field, the molten polymer should be characterized by a suitable viscosity. The molten polymer would be collected by a rotating drum; however, implementation of the numerical control (NC) enables the precise deposition of fiber in $X, Y$ axes. The mentioned approach makes the MES another class of 3D printing techniques [69]. Recent works on the melt electrospinning report that this technique allows for depositing continuous fibers characterized by a diameter less than 1 micrometer, which is comparable to the classic solution of electrospinning [70].

Summarizing information about 3D printing methods are listed in Table 2. 
Table 2. The most popular 3D TE Scaffolds fabrication techniques—applications, advantages, and disadvantages.

\begin{tabular}{|c|c|c|c|}
\hline Method & Applications & Advantages & Disadvantages \\
\hline Bioprinting & $\begin{array}{ll}- & \text { scaffolds manufacturing [71] } \\
- & \text { hydrogels [72] } \\
- & \text { tissue engineering }[73,74] \\
- & \text { cell growth }[75]\end{array}$ & $\begin{array}{ll}- & \text { prints viable cells } \\
- & \text { soft tissue applications }\end{array}$ & $\begin{array}{ll}- & \text { requires support } \\
\text { structures } \\
\text { - } & \text { nozzle limitations } \\
\text { - } & \text { must be not cytotoxic } \\
\text { during process }\end{array}$ \\
\hline $\begin{array}{l}\text { Extrusion-based } \\
\text { methods }\end{array}$ & $\begin{array}{ll}\text { - } & \text { pharmaceuticals }[76,77] \\
\text { - } & \text { scaffold manufacturing [78] } \\
\text { - } & \text { bone tissue engineering [79] } \\
\text { - } & \text { cardiovascular medical } \\
& \text { devices [80] }\end{array}$ & $\begin{array}{ll}- & \text { low cytotoxicity } \\
- & \text { low cost }[81] \\
- & \text { inexpensive printers }\end{array}$ & 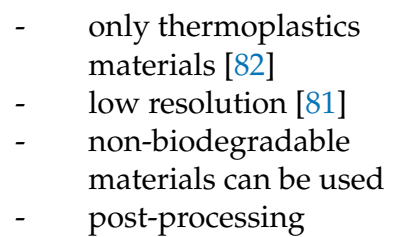 \\
\hline $\begin{array}{l}\text { Indirect methods } \\
\text { (Selective Laser } \\
\quad \text { Sintering; } \\
\text { Stereolitography) }\end{array}$ & $\begin{array}{ll}- & \text { pharmaceutical [83] } \\
- & \text { biomedical manufacturing } \\
& {[84,85]} \\
- & \text { bone tissue engineering } \\
& {[86,87]} \\
- & \text { pharmaceutical }[76] \\
- & \text { drug delivery }[88]\end{array}$ & $\begin{array}{ll}\text { - } & \text { high mechanical } \\
\text { - } & \text { properties } \\
& \text { SLS: powder supporting } \\
\text { the structure } \\
\text { - } & \text { high resolution } \\
\text { - } & \text { smooth surface } \\
\text { - } & \text { short time of the process }\end{array}$ & $\begin{array}{ll}\text { - } & \text { photo-sensitive } \\
\text { materials } \\
\text { - } \quad \text { expensive } \\
\text { - } \quad \text { support systems in case } \\
\text { of very complicated } \\
\text { structures }\end{array}$ \\
\hline
\end{tabular}

\section{Design Strategies of 3D Printed Scaffolds}

\subsection{Idea of Computer-Aided Tissue Engineering}

Modern tissue engineering probably could not exist without the use of various types of computer-aided methods; however, it was not until numerically controlled 3D printers were introduced in TE that all the advantages of computer-aided TE scaffold design became fully available. They are present at almost all possible stages of creating the so-called tissue engineering product. This chapter aims to characterize selected computer-aided design methods and determine the role they play in the process of tissue scaffold design and fabrication by 3D printing techniques. Generally, the role of computer-aided design in tissue engineering is so important that the term CATE (Computer-Aided Tissue Engineering) has emerged and been used in the literature for some time now $[89,90]$.

Figure 8 shows a block diagram that, in simplified terms, describes the operation of the CATE system. The blocks in the diagram symbolize the individual modules of the system. In brief, the task of the CATE system is to generate (based on the defect geometry and a set of appropriately selected criteria) a tissue scaffold design in a form comprehensible for numerically controlled manufacturing devices such as 3D printers.

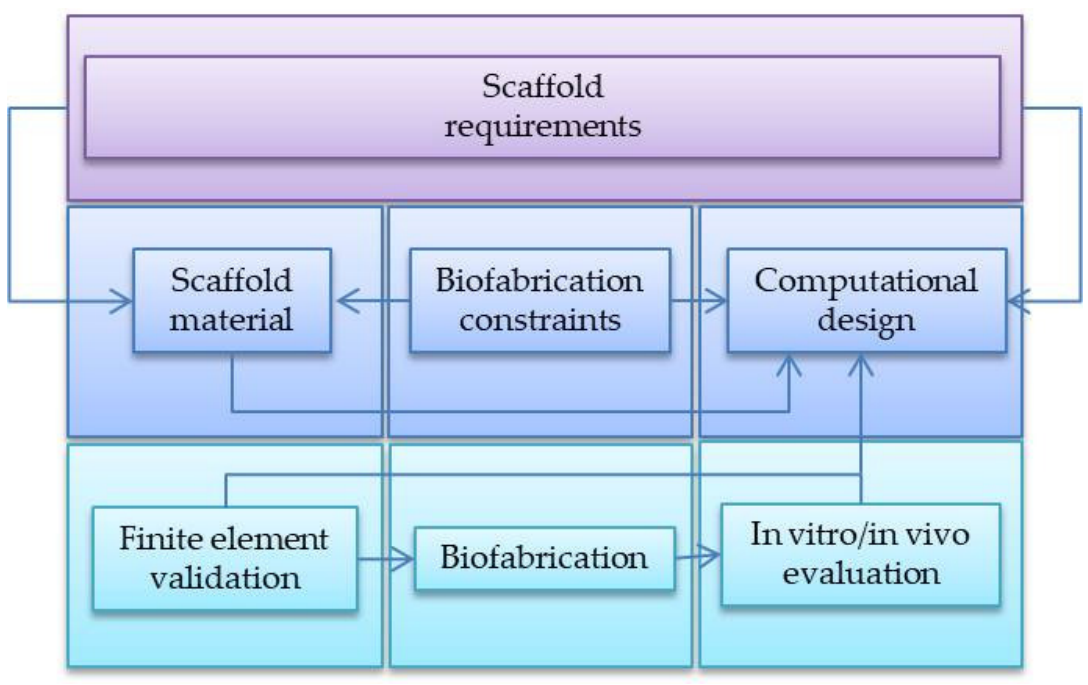

Figure 8. General idea of CATE (based on [90]). 


\subsection{TE Scaffold CAD Geometry Development}

Scaffold geometry can be generated from the start to the finish using CAD software. Such a model is usually described by a set of solid virtual objects with surfaces that precisely define its shape. However, it should be kept in mind that the geometry of the scaffold is a representation of the tissue defect, which usually has an irregular shape. In such a case, a more adequate way to acquire the geometry of the designed scaffold would be to use the reverse engineering techniques enabling one to define precisely the defect shape based on the results of medical imaging by means of computed tomography (CT) or magnetic resonance (MRI). The result of the CT examination is a series of cross-sectional images of the examined object called tomograms. The tomograms usually require filtering of all kinds of noise and artifacts typical for this method. The next stage is the binarization of grayscale tomograms. Based on the series of binarized tomograms, one can create a CAD model of the designed scaffold using commercial or free software (Materialise MIMICS, 3DSlicer, InVesalius). The CAD model is usually saved in one of the neutral formats used by additive manufacturing systems. Probably the most common format used in additive manufacturing systems is the Standard Tessellation Language (STL). It was originally developed for stereolithography but later became popular in other additive manufacturing methods. In the STL format, the shape of an object is approximated by a mesh of triangles; hence, the contents of an STL file are the $\mathrm{x}, \mathrm{y}, \mathrm{z}$ coordinates of each vertex and a vector normal to the triangle plane. In addition to STL, there are other less common geometry storage formats such as SLC (a format containing consecutive sections described by polylines), HGPL (HP Graphical Language), and CLI (Common Layer Interface).

\subsection{Computer-Assisted Optimization of TE Scaffolds}

The optimal tissue scaffold should be characterized by many, often contradictory, features. In turn, the number of design variables describing the tissue scaffold structure is so large that a trial-and-error design usually becomes tedious and inefficient, given that experimental evaluation of the design variants involves lengthy and expensive in vitro and in vivo testing. Design variables that directly affect the quality of the designed scaffold include the mechanical properties of the material used, porosity, scaffold stiffness (dependent on the material and scaffold structure), biological activity, and chemical activity of the chosen material. Several theories have emerged as to what the optimal scaffold should be, but for a long time, there was a lack of proven methods for assisting the design of tissue scaffolds. It was not until the mid-1990s that the first attempts to use computeraided design methods appeared. Until recently, the use of computer methods in tissue engineering was usually limited to the computer-aided design of TE scaffold geometry or the use of in silico models (mainly based on the finite element method (FEM)) at the stage of evaluation of the designed structure. The end of the first decade of this century has brought a significant change in the approach to the problem of tissue scaffold design [91]. At that time, the first attempts were made to use optimization algorithms, both classical ones and those based on artificial intelligence methods [92-94].

\section{Biomaterials Used for TE scaffolds 3D Printing}

The ideal TE scaffold should be characterized by a number of specific properties, such as adequate mechanical strength and stiffness, open porosity, biocompatibility, as well as biodegradability. Meeting the above requirements makes it possible to create a suitable environment for cell growth. To some extent, all the above-mentioned requirements are due to the material used. Among the materials commonly used for TE scaffolds, one can mention natural (e.g., chitin, collagen, cellulose) and synthetic (e.g., polycaprolactone, polyglycolide, and their copolymers) polymers, as well as ceramics and different kinds of additives (hydroxyapatite (HA), carbon nanotubes). Below, the attempt has been made to characterize the main groups of 3D printable materials. At first, the polymers will be discussed, as the most widely used group of materials for tissue engineering. 


\subsection{Polymers}

Polymers represent the main category of materials with high potential for use in 3D printing of TE scaffolds and can be widely used for various tissues' imitation. TE scaffolds may be fabricated from non-biodegradable as well as biodegradable polymers. In the context of tissue engineering, biodegradable polymers generally have more advantages as compared to the non-biodegradable.

\subsubsection{Natural Polymers}

Natural polymers are known to be the right candidates for TE scaffold fabrication, mostly due to their bioactivity, biocompatibility, minimal immune response, as well as natural biodegradability of most of them [95]. As an example of the natural polymers' application in TE, one can mention the work of [96] reporting fabrication of TE scaffolds for cartilage regeneration made of bacterial cellulose. Another study confirms that cellulose from Acetobacter xylinum can be used in the cartilage regeneration [97]. Collagen and chitosan also belong to the polymers widely investigated and applied in TE [98]. All of the above-mentioned materials are known for supporting the cell proliferation and viability [99].

Another biocompatible and easily accessible natural material is gelatine, being an irreversible hydrolyzed form of collagen [100]. There are numerous attempts of using gelatine as biomaterial for 3D printing of TE scaffolds. In the work by [101], the gelatine/hydroxyapatite composite was investigated as material for 3D printing scaffolds for stem cells' chondrogenic differentiation. Pure gelatine 3D scaffolds were proven to be a good environment for the proliferation and viability of hepatocyte cells [99].

In the work by [102], high proliferation and viability of mesenchymal stem cells cultured on/in collagen/agarose scaffolds wer observed.

\subsubsection{Synthetic Polymers}

The usefulness of biodegradable synthetic polymers (mainly aliphatic polyesters such as PCL or PLGA) in TE has already been investigated for many years $[103,104]$. The biodegradable aliphatic polyesters are characterized by relatively low toxicity [105]; however, the acidic oligomeric release, being the effect of polymer hydrolytic degradation, can initiate the inflammatory reaction [106], negatively affecting the tissue regeneration process [107]. Other research works on the degradation kinetics of 3D-printed TE scaffolds made from various aliphatic polyesters, have shown the differences in the degree of the degradation for PLGA $(40,000-75,000 \mathrm{Da})$ and PCL $(\mathrm{Mw}=114,000 \mathrm{Da})$ as $18 \%$ and $56 \%$ on day 14 and day 28 for PLGA, and 33\% on day 21 and 39\% on day 28 for PCL, respectively [108]. TE scaffolds made of aliphatic polyesters are known to be successfully applied in the tissue loss treatment $[109,110]$ including bone regeneration $[111,112]$. The degradation time of TE scaffolds made of aliphatic polymers can be thoroughly controlled [113]. The predominant degradation mechanism for all bioresorbable polyesters used in bioengineering is hydrolysis occurring in enzymatic conditions. From the moment an implant (e.g., TE scaffold) is placed in the living organism, water, which is one of the main components of the physiological environment, penetrates the polymer matrix at various speeds [114]. This penetration speed depends on many factors, including the hydrophilicity of the implant material. Water molecules cause weakening and consequently breaking of ester bonds, which are responsible for the cohesion of polymer chains. It was found that the degradation of some objects made from aliphatic polymers proceeds heterogeneously in such a way that the central part of the object degrades faster than the areas in direct contact with the environment. One can find numerous examples of aliphatic polyesters' application in tissue engineering [115].

Copolymerization is another way of effectively controlling the final properties of 3Dprinted TE scaffolds. Copolymers such as PCL with a PEG $(\mathrm{Mn}=1000)$ addition [116] or PCL $(\mathrm{Mw}=2000)$ with a PLGA addition [117] were synthesized for controlled degradation dedicated to drug-release applications. Different types of printable copolymers, such as 
poly(hydroxybutyrate) (PHB) [118], poly(propylene fumarate) [119] (PPF), and polyglycolic acid (PGA) [120], were also tested.

Systematic studies concerning bone tissue engineering have been carried out for years. A multitude of 3D-printed scaffolds made of different polyesters and their copolymers were tested under in vivo and in vitro conditions to investigate their abilities for the neovascularization and the bone ingrowth [121]. Many works concern the 3D printing of polymeric scaffolds filled with growth factors such as TGF- $\beta$ and BMP-2 which enable obtaining specifically vascularized bone constructs [122,123].

\subsubsection{Hydrogels}

Hydrogels belong to crosslinked polymers having the property of binding relatively large amounts of water. They can be made of synthetic or natural polymers such as collagen or alginate $[124,125]$. Due to their relatively high water content, hydrogels are quite biocompatible and have relatively low mechanical properties. Because of their mechanical similarity to the native tissue, their transport/diffusion properties and high biocompatibility, hydrogels are among the most promising materials from which tissue scaffolds can be fabricated. Moreover, they allow relatively easy and safe immobilization of biologically active molecules. So far, various bioink biomaterials, such as gelatinmethacrylates, agarose, alginate, collagen, chitin, silk, hyaluronic acid, cellulose, and their mixtures have been used together with various crosslinking methods such as click chemistry, ionic/hydrogen bonding, or chemical bonding via radical initiators. Among them, alginates are the most attractive for bioprinting, mainly due to their ability to form a soft gel matrix in a low-aggressive environment for living cells and encapsulated biomolecules. One of the important properties of alginate is its ability to form gels by ionic crosslinking with calcium cations. However, environmental factors such as buffer acidity or temperature can easily affect the condition of the hydrogel material and its degradation, leading to the consequent loss of the biomolecules contained in the hydrogel matrix. Polymers such as poly(ethylene glycol) diacrylate (PEGDA) or natural gelatin methacrylate (GelMA) can also be used for the preparation of hydrogels [126,127]. Hydrogels often are used as a component of hybrid TE scaffolds mimicking the soft tissues (e.g., muscles tissue) [128].

In Table 3, polymer scaffolds with applications and printing methods are summarized.

Table 3. Polymer scaffolds with applications and printing methods.

\begin{tabular}{cccc}
\hline Polymer Scaffolds & Printing Method & Applications & Refs. \\
\hline Chitosan/Rhizopus mycelia/Fungi & - & Bone regeneration & {$[129]$} \\
PCL & Direct Printing & Heart and cartilage tissue & {$[130]$} \\
PCL & FDM & Tissue engineering & {$[131]$} \\
PCL/alginate-based hydrogel & Extrusion & Bone tissue engineering & {$[132]$} \\
PCL/PLA & Bioextrusion & Tissue engineering & {$[133]$} \\
PCL, chitosan & FDM & Bone tissue engineering & {$[134]$} \\
PCL/HA & FDM & Tissue engineering & {$[135]$} \\
PCL/silk & Extrusion & Tissue engineering & {$[136]$} \\
PCL/castor oil & FDM & Bone tissue engineering & {$[137]$} \\
PCL & FDM & Bone tissue engineering & {$[138]$} \\
PCL/HA & Indirect printing & Tissue engineering & {$[139]$} \\
PCL/diamond & Extrusion & Tissue engineering & {$[140]$} \\
PLALA, collagen & FDM & Tendon-bone & {$[141]$} \\
PLA, collagen & FDM & Bone tissue engineering & {$[142]$} \\
PLA & FDM & Bone tissue engineering & {$[143]$} \\
PLCL & FDM & Tissue engineering & {$[144]$} \\
PLA/ABS & FDM & Bone tissue engineering & {$[145]$} \\
PLA & FDM & Bone tissue engineering & {$[146]$} \\
PLA/cellulose & Extrusion & Tissue engineering & {$[147]$} \\
\hline
\end{tabular}


Table 3. Cont.

\begin{tabular}{|c|c|c|c|}
\hline Polymer Scaffolds & Printing Method & Applications & Refs. \\
\hline PCL, PLGA, collagen, gelatin & FDM, extrusion & Bone tissue engineering & [148] \\
\hline PLCL/dECM & Hot melting Extrusion & Tissue regeneration & [149] \\
\hline Alginate, PEGDA, CS & Extrusion & Kidney & [150] \\
\hline Alginate & Extrusion & Microphysiologic studies & {$[148,151]$} \\
\hline Alginate, collagen, agarose & Extrusion & Cartilage & [152] \\
\hline Alginate, gelatin & Extrusion & Mutlicellular tissue & [153] \\
\hline GelMA/Alg-PEG-M & Extrusion & Vascular & [154] \\
\hline Agarose, collagen & Extrusion & Kidney & [102] \\
\hline PCL & 3D printing & $\mathrm{HOb}$ & [155] \\
\hline PC & 3D printing & Bone tissue engineering & [156] \\
\hline Me-HA/GelMA & Extrusion & Cardiac tissues & [157] \\
\hline Me-HA & Extrusion & Bone tissue engineering & [158] \\
\hline Agarose/carbon nanotubes & Extrusion & Biosensors, various tissues & [159] \\
\hline PVA, phytagel & Extrusion & Soft connective tissue & [160] \\
\hline Gelatin/silk fibroin & Extrusion & Skin & [161] \\
\hline Hyaluronic acide/gelatin & Extrusion & Cardiac & [162] \\
\hline Collagen/chitosan & Extrusion & Neural tissue engineering & [163] \\
\hline Alginate/gelatin & Extrusion & Tumor microenvironment & [164] \\
\hline Pluronics/gelatin methacrylate & Extrusion & Vascular & [165] \\
\hline Alginate & Extrusion & Liver & [166] \\
\hline NFC, alginate, hyaluronic acid & Extrusion & Cartilage & [167] \\
\hline NFC/alginate & Extrusion & Cartilage & [168] \\
\hline Collagen & Extrusion & Skin & [169] \\
\hline Porcine skin powder & Bioprinting & Soft tissue engineering & [170] \\
\hline HA, PLGA & Stereolithography & Bone tissue engineering & [171] \\
\hline PLA/PCL/HA & Extrusion & Cartilage defects treatment & [172] \\
\hline PEGDA, polydiacetylene nanoparticles & Stereolithography & Liver tissues & [173] \\
\hline $\mathrm{VE} / \mathrm{VC}$ & DLP & Bone tissue engineering & [174] \\
\hline Cellulose nanocrystal & DIW & Multicellular tissue & [175] \\
\hline PLGA & Inkjet & Liver tissues & [115] \\
\hline
\end{tabular}

PCL—polycaprolactone; PLA—polylactic acid; HA—hydroxyapatite; PLGA—poly Lactic-co-glycolic acid; PLCL—Polyl-lactide-co$\varepsilon$-caprolactone; ABS-acrylonitrile butadiene styrene; PEGDA-poly(ethylene glycol) diacrylate; CS—cellularized structures; MeHA - methacrylated hyaluronic acid; GelMA—-metharylated gelatin; Alg-PEG-M—alginate, poly ethylene glycol tetra acrylate; PC— polycarbonate; PVA—polyvinyl alcohol; NFC—nanofibrillated cellulose; VE—vinylester, VC—vinylcarbonate.

\subsection{Other Materials}

Ceramic and composite scaffolds contain organic salts of phosphate and calcium. The main advantage of printed 3D ceramic scaffolds is good biocompatibility and very high mechanical strength [176]. Ceramic scaffolds are excellent candidates for bone tissue engineering due to their mineralization ability [177]. Hydroxyapatite (HA), which is a bone component [178], is an attractive material for creating complex 3D structures with mechanical properties similar to those of a bone. These types of 3D-printed scaffolds are widely investigated in regenerative medicine [179]. The above-mentioned ceramic materials can be mixed with a polymer, creating a composite. It was proven that these materials have the ability to support vascularization properties [144,180]. Materials having mechanical properties similar to a bone, such as bioglass, silica, graphene oxide, and zirconium titanate, are often used as the TE scaffold components [181]. The possibility of the fabrication of feasible TE scaffolds made of the polymeric composites containing the mentioned additives was investigated by many groups [182]. Numerous 3D-printed ceramic materials are treated by freeze-drying and sintering to improve cytocompatibility and mechanical properties [183]. TE scaffolds printed from bioactive glass-ceramics with a unique triphasic structure containing hardystonite, gahnite, and strontium were shown to have $34 \%$ porosity and a strength similar to that of a bone being $110 \mathrm{MPa}$ [180].

An addition of bioceramics in polymer scaffolds results in excellent properties, higher biocompatibility, and controlled degradation. Furthermore, bioactive ceramics are gaining 
more and more attention due to their excellent osteogenic properties [184]. Calcium phosphates $(\mathrm{CaPs})$ are the most frequently used bioceramics in tissue engineering applications, due to their similarity to the chemical structure of a bone.

Table 4 summarizes ceramic scaffolds with an addition of a polymer(s) and the printing method used.

Table 4. Ceramic scaffolds with/without an addition of a polymer(s) and the printing method.

\begin{tabular}{|c|c|c|c|}
\hline Ceramics & Polymer(s) & Printing Method & Refs. \\
\hline $\mathrm{BCP}$ & PCL & Inkjet & [185] \\
\hline $\mathrm{HA} / \mathrm{TCP}$ & - & $\begin{array}{l}\text { digital light processing } \\
\text { (DLP)-type 3D printing system }\end{array}$ & [186] \\
\hline $\mathrm{BCP}$ & PLGA, PCL, collagen & FDM & [187] \\
\hline$\beta-\mathrm{TCP}$ & PEGDA & Stereolithography & [188] \\
\hline $\begin{array}{l}\text { zirconia polycrystal (3Y-TZP) and } \\
\text { Pluronic hydrogel ceramic paste }\end{array}$ & $\begin{array}{l}\text { Bisphenol A glycerolate dimethacrylate } \\
\text { (Bis-GMA) and tri(ethylenglycol) } \\
\text { dimethacrylate (TEGDMA) copolymer }\end{array}$ & $\begin{array}{l}\text { 3D-printed by robocasting } \\
\text { method }\end{array}$ & [189] \\
\hline HA & PLA & FDM & {$[190,191]$} \\
\hline HA & PCL & FDM & [192] \\
\hline HA, bone marrow clots & PCL & FDM & [193] \\
\hline HA, PLGA microspheres & PCL & FDM & [194] \\
\hline HA, solvent system & PLGA & Extrusion & [195] \\
\hline HA, $\alpha$-TCP, phosphoric acid & Collagen & Inkjet & [196] \\
\hline Ti6Al4V & & Laser beam melting & [197] \\
\hline Titanium & PLA & $\begin{array}{l}\text { 3D printing based on Fused } \\
\text { Filament Fabrication (FFF) }\end{array}$ & [198] \\
\hline Mesoporous silica, CPC & & Extrusion & [199] \\
\hline Titanium, platelets & Gelatin & Laser sintering & [200] \\
\hline CPC & & Extrusion & [201] \\
\hline Calcium silicate & PCL & Laser sintering & [202] \\
\hline Mesoporous bioglass, CS & & Extrusion & [203] \\
\hline Wallastonite, magnesium & & Extrusion & [204] \\
\hline BCP, HPMC, ZrO2 & & Extrusion & [205] \\
\hline CS & & Inkjet & [206] \\
\hline Silica, calcium carbonate & & Laser assisted gelling & [207] \\
\hline Tricalcium phosphate & & Inkjet & [208] \\
\hline Graphene & PCL & FDM & [209] \\
\hline
\end{tabular}

$\mathrm{BCP}$-tricalcium phosphate-hydroxyapatite bioceramic; $\mathrm{PCL}$-polycaprolactone; HA-hydroxyapatite; TCP-tricalcium phosphate; PLGA — poly Lactic-co-glycolic acid; PEGDA—poly(ethylene glycol) diacrylate; CPC—calcium phosphate cement; HPMC—Hydroxypropyl methylcellulose; CS-cellularized structures.

\section{Advanced 3D-Printed TE Constructs-Examples}

In this chapter, the selected latest advances in the 3D printing of TE scaffolds are presented, focusing on the new possibilities of the recapitulation of complex tissue structures offered by modern 3D printing techniques.

\subsection{Nervous Tissue}

The central nervous system (CNS) and the peripheral nervous system (PNS) are the most challenging tissues for repair. The 3D printing in vitro model of a brain was developed by forming microchannels with collagen, using needles and a 3D printing frame. Mouse brain cells were cultured on the collagen microchannels, which resulted in regeneration of the brain microvasculature. This experiment has shown that the model of the brainblood barrier can be used for pathological and physiological tests and many applications, such as drug delivery, tissue regeneration, and tissue engineering [210]. Some studies are devoted to the 3D printing of nerve conduits. In work by [211], cryopolymerized gelatin methacryloyl (cryoGelMA) gel cellularized with adipose-derived stem cells (ASCs) were used for the 3D printing of cellularized conduits for peripheral nerve regeneration. The 
re-innervation ability of the fabricated conduits was proven in vivo. It is worth mentioning that $3 \mathrm{D}$ printing was used for the fabrication of patient-specific casting molds.

\subsection{Ocular Tissues}

Interest in 3D printing techniques in ophthalmology is still growing; however, the majority of 3D printing applications does not concern tissue engineering. Here are examples of works on using 3D printing for ocular tissue regeneration: In the work by [212], an attempt of the reconstruction of a $3 \mathrm{D}$ retina is reported. The retina-like structure containing adult rat retinal ganglion cells and glia were 3D printed. It was proven that these types of retinal cells can be successfully printed without loss of viability and certain phenotypic features. Another example of the application of 3D printing in ocular tissue engineering would be the work by [213] concerning the fabrication of the TE corneal scaffold made of collagen-based bio-ink containing encapsulated corneal keratocytes.

\subsection{Ear}

The computer-aided design has been used to create the bionic human ear. A hydrogel matrix containing cells and a conductive polymer with the addition of silver nanoparticles were used during printing - bioprinted in the shape of a human ear. The studies allowed control of the signals from the cochlea-shaped electrodes. The in vitro culture was provided on the cartilage tissues on every side of the inductive coil. The printed ear was found to enhance the auditory sensing. Another study showed that the printed ear can be formed by $3 \mathrm{D}$ bioprinting with the subject's lipid tissue and an auricular cartilage. Adipocytes and chondrocytes differentiated from the adipose-derived stromal cells were enclosed in hydrogels and then placed at the lipid and cartilage tissue [214-216].

\subsection{Kidney}

Scaffolds from PEGDA with the addition of sodium alginate and calcium sulfate were tested [150]. After fabrication, scaffolds were crosslinked using UVclight, and subsequent human embryonic kidney cells (HEK) were cultured. It was shown that the mentioned composite materials are characterized by properties supporting the proliferation and viability of the cells. In the work of Lawlor et al. [217], extrusion-based 3D bioprinting was applied for the generation of human kidney organoids (the organoid is a simplified version of a living organ produced in vitro). The used fabrication method enables for precise manipulation of organoid size and cell number and conformation. The developed in vitro model of kidney organoids could be used for drug testing or disease modeling.

\subsection{Skin}

Using a laser-assisted method, a 3D-printed skin was developed. Collagen type I and Matriderm (for matrix stabilization) were mixed and cultured with fibroblasts and keratinocytes. The experiment was also performed at in-vivo conditions by placing a bioprinted construct on the murine skin. In the effect, mainly an epidermis forming was observed [218]. In [219], the method of biofabrication of skin equivalents (SE) that are bioprinted using open-market bioprinter, made with fibroblasts and keratinocytes suspended in the gelatin-based hydrogel, was discussed. SE construct layers were extruded directly onto the multi-well plate. Three levels comprise the developed structure: dermis, laminin/entactin basal layer, and epidermis. The developed SE may be used for in vitro skin disease modeling.

\subsection{Cancer Models}

Recent progress in bioprinting enables the development of 3D in vitro models of various kinds of cancerous tissue [220]. Such models enable the design of patient-specific therapies as well as for the investigation of the processes related to carcinogenesis, such as tumor extravasation [221]. Bioprinted cancer models usually are composed of multiple layers containing different cell types including tumor cells (usually patient-derived cells), 
the extracellular matrix, growth factors, and vasculature [222]. Bioprinted tumor models should recapitulate the actual tumor heterogeneity. They enable anti-cancer therapy screening as well as the investigation of cell-cell and cell-matrix interactions. Bioprinted cancer models are characterized by great advantages over 2D in vitro models, which cannot mimic the structural complexity of tumors.

\subsection{Bone and Cartilage Tissue Engineering}

Bone and cartilage defects repair is one of the most common regenerative procedures. The principal part of bone and cartilage tissue engineering is to replace a damaged bone. Therefore, 3D printing techniques try to print a structure of artificial bone with required properties, such as appropriate mechanical properties, shape, and size [223]. The major causes of bone and cartilage defects are trauma, congenital anomalies, and tissue resection due to cancer. Such treatments such as autogenous bone grafting are characterized by several disadvantages, such as unsuitable donor tissue availability or donor site morbidity. On the other hand, allogeneic bone grafts are avoided mainly due to the risk of disease transmission. Over the past several years, the importance of therapies using the 3D-printed TE scaffolds has been growing gradually. TE scaffolds enable seeded cells to adhere, migrate, grow, and differentiate into chondrogenesis and osteogenesis.

Here are examples of recently published works on the application of 3D printing in bone and cartilage regeneration: Most of the proposed solutions are based on the combination of several different materials - ceramic, polyesters, and hydrogels [224-226] Quite often, to improve the cell-seeding efficiency and osteoinductivity, an injectable hydrogel is incorporated into a 3D-printed porous structure to form a hybrid scaffold [227]. Despite the fact that multiple types of materials are used to fabricate 3D-printed bone scaffolds, biodegradable aliphatic polyesters remain the gold standard [228,229]. On the other hand, hydrogels are the most popular group of materials for the cartilage TE [230]. Osteochondral scaffolds remain a particular challenge for tissue engineering. Typically, the fabrication of osteochondral scaffolds requires a combination of several printing techniques and materials [231], as it should be remembered that osteochondral scaffolds are usually bi- or even tri-phasic.

\section{Future Directions and Conclusions}

Various approaches in scaffolds' formation for use in tissue engineering applications are experiencing rapid advances. Regarding the development of 3D-printed scaffolds, the most important goal is to mimic the complexity of a natural living tissue truly. Its structure should have appropriate mechanical properties, pore size distribution, and pores' arrangement (allowing cell migration and diffusion). While numerous tissues were successfully cultured as proof of the principle, the development of a fully functional complex human-size organ is still pending.

The types of fabrication methods and the materials provided in this review serve to improve current TE procedures.

\section{Drawbacks and Future Directions of the 3D Printing of TE Scaffolds}

Even though 3D printing is extremely promising from a TE point of view, it is characterized by several limitations related mainly to the lack of legal regulations and standardized procedures. Moreover, the fabrication of any TE product requires advanced and costly infrastructure that may include software, robust computer workstations, 3D printers, and cell culture laboratory facilities. Nowadays, most TE product implantation attempts were realized in cooperation between hospitals and research institutes. Usually, such cooperation was of an ad hoc nature and did not go beyond the research study. It is clear that to increase the availability of 3D printing in TE applications, the current collaboration model between engineers and doctors needs to be modified. One of the ideas is to establish regional 3D printing centers, adequately equipped and staffed [232]. Such centers would contribute to 
more efficient use of the equipment and human resources. The idea is that such centers could serve many medical facilities in a given region.

A major problem facing researchers, doctors, and engineers is the lack of an established legal framework and procedures for validating tissue-engineered products. It is a wellknown fact that existing legal provisions hinder the scale-up from the laboratory to a larger scale. Attesting of patient-specific TE products is also problematic from the point of view of current standards.

Another drawback related to the 3D printing of TE scaffolds is a lack of standardized terminology used to systematize the field, which is a characteristic of new and rapidly developing fields of knowledge.

Still, the actual issue and the most challenging step involve a translation of the technology to the next level-the availability to the patients, giving a chance to improve the quality of their lives. Not so long ago, the 3D-printing-assisted cultivation of TE constructs has been started using the patient's cells $[233,234]$, and now the symbol of the cutting-edge technology for TE is $4 \mathrm{D}$ printing [235]. This advanced 3D-printed technology adds a fourth dimension - time - to currently-used 3D printing. It enables the fabrication of TE scaffolds having a self-assembly ability. This technique assumes the use of smart materials characterized by the ability to change their properties under the influence of an applied stimulus (e.g., thermoresponsive shape memory polymers). Furthermore, 4D printing can be used for the fabrication of TE scaffolds enabling the mechanical stimulation of living cells by the external signal (e.g., magnetic field) [236]. Vascularization is another challenging goal, and the new generation of bioprinters with multiple print-heads seems very promising. Loaded with various cell types, they are expected to reconstruct and recapitulate the factual complexity of a multi-tissue organ.

Future activities should include testing materials for medical-oriented 3D printing methods, creating new printers to provide high precision of TE scaffolds, making unified standards for scaffolds, strengthening market supervision to optimize implants for clinical use, and establishing a 3D printing platform to enhance communication among research institutes, hospitals, and companies. These advancements should further promote the development of 3D-printed tissue engineering technology.

Author Contributions: Conceptualization, A.Z., M.M.-H., A.G. and P.S.; validation, A.G., P.S.; investigation, A.Z., M.M.-H.; writing—original draft preparation, A.Z., M.M.-H.; writing—review and editing, A.G., P.S.; visualization, A.Z., M.M.-H., A.G. and P.S.; supervision, A.G., P.S. All authors have read and agreed to the published version of the manuscript.

Funding: The Article Processing Charge (APC) was covered by the Project no. POWR.03.02.0000-1028/17-00 implemented under the Operational Program Knowledge Education Development 2014-2020, co-financed by the European Social Fund.

Institutional Review Board Statement: Not applicable.

Informed Consent Statement: Not applicable.

Data Availability Statement: No new data were created or analyzed in this study.

Conflicts of Interest: The authors declare no conflict of interest.

\section{References}

1. Deng, C.; Chang, J.; Wu, C. Bioactive Scaffolds for Osteochondral Regeneration. Degener. Musculoskelet. Dis. Pathol. Treat. 2019, 17, 15-25. [CrossRef] [PubMed]

2. Zaszczynska, A.; Sajkiewicz, P.; Gradys, A. Piezoelectric Scaffolds as Smart Materials for Neural Tissue Engineering. Polymers 2020, 12, 161. [CrossRef] [PubMed]

3. Zaszczyńska, A.; Gradys, A.; Sajkiewicz, P. Progress in the Applications of Smart Piezoelectric Materials for Medical Devices. Polymers 2020, 12, 2754. [CrossRef] [PubMed]

4. Kowalewicz, K.; Vorndran, E.; Feichtner, F.; Waselau, A.-C.; Brueckner, M.; Meyer-Lindenberg, A. In-Vivo Degradation Behavior and Osseointegration of 3D Powder-Printed Calcium Magnesium Phosphate Cement Scaffolds. Materials 2021, 14, 946. [CrossRef] 
5. Seoane-Viaño, I.; Januskaite, P.; Alvarez-Lorenzo, C.; Basit, A.W.; Goyanes, A. Semi-Solid Extrusion 3D Printing in Drug Delivery and Biomedicine: Personalised Solutions for Healthcare Challenges. J. Control. Release Off. J. Control. Release Soc. 2021, 332, 367-389. [CrossRef]

6. $\quad$ Lee, V.; Singh, G.; Trasatti, J.P.; Bjornsson, C.; Xu, X.; Tran, T.N.; Yoo, S.-S.; Dai, G.; Karande, P. Design and Fabrication of Human Skin by Three-Dimensional Bioprinting. Tissue Eng. Part C Methods 2014, 20, 473-484. [CrossRef]

7. Markstedt, K.; Mantas, A.; Tournier, I.; Martínez Âvila, H.; Hägg, D.; Gatenholm, P. 3D Bioprinting Human Chondrocytes with Nanocellulose-Alginate Bioink for Cartilage Tissue Engineering Applications. Biomacromolecules 2015, 16, 1489-1496. [CrossRef]

8. Cui, H.; Zhu, W.; Nowicki, M.; Zhou, X.; Khademhosseini, A.; Zhang, L.G. Hierarchical Fabrication of Engineered Vascularized Bone Biphasic Constructs via Dual 3D Bioprinting: Integrating Regional Bioactive Factors into Architectural Design. Adv. Healthc. Mater. 2016, 5, 2174-2181. [CrossRef]

9. Laronda, M.M.; Rutz, A.L.; Xiao, S.; Whelan, K.A.; Duncan, F.E.; Roth, E.W.; Woodruff, T.K.; Shah, R.N. A Bioprosthetic Ovary Created Using 3D Printed Microporous Scaffolds Restores Ovarian Function in Sterilized Mice. Nat. Commun. 2017, 8, 15261. [CrossRef]

10. OPTN: Organ Procurement and Transplantation Network-OPTN. Available online: https://optn.transplant.hrsa.gov/ (accessed on 5 May 2021).

11. Singh, D.; Thomas, D.J.; Motamarry, A. 13-3D printing future perspective in medicine. In 3D Printing in Medicine and Surgery; Woodhead Publishing Series in Biomaterials; Thomas, D.J., Singh, D., Eds.; Woodhead Publishing: Cambridge, UK, 2021; pp. 265-270. ISBN 978-0-08-102542-0.

12. Wibowo, A.; Vyas, C.; Cooper, G.; Qulub, F.; Suratman, R.; Mahyuddin, A.I.; Dirgantara, T.; Bartolo, P. 3D Printing of Polycaprolactone-Polyaniline Electroactive Scaffolds for Bone Tissue Engineering. Materials 2020, 13, 512. [CrossRef]

13. Moczulska, M.; Bitar, M.; Święszkowski, W.; Bruinink, A. Biological Characterization of Woven Fabric Using Two- and ThreeDimensional Cell Cultures. J. Biomed. Mater. Res. A 2012, 100A, 882-893. [CrossRef]

14. Stevens, M.M.; George, J.H. Exploring and Engineering the Cell Surface Interface. Science 2005, 310, 1135-1138. [CrossRef]

15. Hollister, S.J. Porous Scaffold Design for Tissue Engineering. Nat. Mater. 2005, 4, 518-524. [CrossRef]

16. Navarro, M.; Michiardi, A.; Castaño, O.; Planell, J. A Biomaterials in Orthopaedics. J. R. Soc. Interface 2008, 5, 1137-1158. [CrossRef]

17. Nair, L.S.; Laurencin, C.T. Polymers as Biomaterials for Tissue Engineering and Controlled Drug Delivery. Adv. Biochem. Eng. Biotechnol. 2006, 102, 47-90. [CrossRef]

18. Abdollahiyan, P.; Oroojalian, F.; Mokhtarzadeh, A. The Triad of Nanotechnology, Cell Signalling, and Scaffold Implantation for the Successful Repair of Damaged Organs: An Overview on Soft-Tissue Engineering. J. Control. Release 2021, 332, 460-492. [CrossRef]

19. Badekila, A.K.; Kini, S.; Jaiswal, A.K. Fabrication Techniques of Biomimetic Scaffolds in Three-Dimensional Cell Culture: A Review. J. Cell. Physiol. 2021, 236, 741-762. [CrossRef]

20. Bongiovanni Abel, S.; Montini Ballarin, F.; Abraham, G.A. Combination of Electrospinning with Other Techniques for the Fabrication of 3D Polymeric and Composite Nanofibrous Scaffolds with Improved Cellular Interactions. Nanotechnology 2020, 31, 172002. [CrossRef]

21. Sajkiewicz, P.; Heljak, M.K.; Gradys, A.; Choińska, E.; Rumiński, S.; Jaroszewicz, T.; Bissenik, I.; Święszkowski, W. Degradation and Related Changes in Supermolecular Structure of Poly(Caprolactone) in Vivo Conditions. Polym. Degrad. Stab. 2018, 157, 70-79. [CrossRef]

22. Szewczyk, P.K.; Gradys, A.; Kim, S.K.; Persano, L.; Marzec, M.; Kryshtal, A.; Busolo, T.; Toncelli, A.; Pisignano, D.; Bernasik, A.; et al. Enhanced Piezoelectricity of Electrospun Polyvinylidene Fluoride Fibers for Energy Harvesting. ACS Appl. Mater. Interfaces 2020, 12, 13575-13583. [CrossRef]

23. Kaniuk, Ł.; Ferraris, S.; Spriano, S.; Luxbacher, T.; Krysiak, Z.; Berniak, K.; Zaszczynska, A.; Marzec, M.M.; Bernasik, A.; Sajkiewicz, P.; et al. Time-Dependent Effects on Physicochemical and Surface Properties of PHBV Fibers and Films in Relation to Their Interactions with Fibroblasts. Appl. Surf. Sci. 2021, 545, 148983. [CrossRef]

24. Ura, D.P.; Rosell-Llompart, J.; Zaszczyńska, A.; Vasilyev, G.; Gradys, A.; Szewczyk, P.K.; Knapczyk-Korczak, J.; Avrahami, R.; Šišková, A.O.; Arinstein, A.; et al. The Role of Electrical Polarity in Electrospinning and on the Mechanical and Structural Properties of As-Spun Fibers. Materials 2020, 13, 4169. [CrossRef] [PubMed]

25. Ghosal, K.; Augustine, R.; Zaszczynska, A.; Barman, M.; Jain, A.; Hasan, A.; Kalarikkal, N.; Sajkiewicz, P.; Thomas, S. Novel Drug Delivery Systems Based on Triaxial Electrospinning Based Nanofibers. React. Funct. Polym. 2021, 163, 104895. [CrossRef]

26. Ulbricht, M. Design and Synthesis of Organic Polymers for Molecular Separation Membranes. Curr. Opin. Chem. Eng. 2020, 28, 60-65. [CrossRef]

27. Sin, D.; Miao, S.; Liu, G.; Fan, W.; Chadwick, G.; Yan, C.; Friis, T. Polyurethane (PU) Scaffolds Prepared by Solvent Casting/Particulate Leaching (SCPL) Combined with Centrifugation. Mater. Sci. Eng. C Mater. Biol. Appl. 2010, 30, 78-85. [CrossRef]

28. Parham, S.; Kharazi, A.Z.; Bakhsheshi-Rad, H.R.; Ghayour, H.; Ismail, A.F.; Nur, H.; Berto, F. Electrospun Nano-Fibers for Biomedical and Tissue Engineering Applications: A Comprehensive Review. Materials 2020, 13, 2153. [CrossRef]

29. Nyamweya, N.N. Applications of Polymer Blends in Drug Delivery. Future J. Pharm. Sci. 2021, 7, 18. [CrossRef]

30. Subramaniyan, M.; Eswaran, P.; Appusamy, A.; Srimannarayana Raju, P.; Rahini, V.; Madhumitha, T.R.; Thisha, R. A Survey on Applications of Additive Manufacturing Techniques in Tissue Engineering. Mater. Today Proc. 2021. [CrossRef] 
31. Yang, S.; Leong, K.F.; Du, Z.; Chua, C.K. The Design of Scaffolds for Use in Tissue Engineering. Part I. Traditional Factors. Tissue Eng. 2001, 7, 679-689. [CrossRef]

32. Ikeda, T.; Ikeda, K.; Yamamoto, K.; Ishizaki, H.; Yoshizawa, Y.; Yanagiguchi, K.; Yamada, S.; Hayashi, Y. Fabrication and Characteristics of Chitosan Sponge as a Tissue Engineering Scaffold. BioMed. Res. Int. 2014, 2014, e786892. [CrossRef]

33. Drury, J.L.; Mooney, D.J. Hydrogels for Tissue Engineering: Scaffold Design Variables and Applications. Biomaterials 2003, 24, 4337-4351. [CrossRef]

34. Zaszczyńska, A.; Sajkiewicz, P.Ł.; Gradys, A.; Tymkiewicz, R.; Urbanek, O.; Kołbuk, D. Influence of Process-Material Conditions on the Structure and Biological Properties of Electrospun Polyvinylidene Fluoride Fibers. Bull. Pol. Acad. Sci. Tech. Sci. 2020, 68. [CrossRef]

35. Gibson, I.; Rosen, D.; Stucker, B.; Khorasani, M. Development of Additive Manufacturing Technology. In Additive Manufacturing Technologies; Gibson, I., Rosen, D., Stucker, B., Khorasani, M., Eds.; Springer International Publishing: Cham, Switzerland, 2021; pp. 23-51. ISBN 978-3-030-56127-7.

36. Jain, K.; Shukla, R.; Yadav, A.; Ujjwal, R.R.; Flora, S.J.S. 3D Printing in Development of Nanomedicines. Nanomaterials 2021, 11, 420. [CrossRef]

37. Wang, C.; Huang, W.; Zhou, Y.; He, L.; He, Z.; Chen, Z.; He, X.; Tian, S.; Liao, J.; Lu, B.; et al. 3D Printing of Bone Tissue Engineering Scaffolds. Bioact. Mater. 2020, 5, 82-91. [CrossRef]

38. Ong, C.S.; Yesantharao, P.; Huang, C.Y.; Mattson, G.; Boktor, J.; Fukunishi, T.; Zhang, H.; Hibino, N. 3D Bioprinting Using Stem Cells. Pediatr. Res. 2018, 83, 223-231. [CrossRef]

39. Egan, P.F. Integrated Design Approaches for 3D Printed Tissue Scaffolds: Review and Outlook. Materials 2019, 12, 2355. [CrossRef]

40. Sachs, E.M.; Haggerty, J.S.; Cima, M.J.; Williams, P.A. Three-Dimensional Printing Techniques. CIRP Ann. 1993, 42, 257-260. [CrossRef]

41. Cima, M.J.; Sachs, E.; Cima, L.G.; Yoo, J.; Khanuja, S.; Borland, S.W.; Wu, B.; Giordano, R.A. Computer-Derived Microstructures by 3D Printing: Sio- and Structural Materials. Mater. Sci. 1994. [CrossRef]

42. Griffith, L.G.; Wu, B.; Cima, M.J.; Powers, M.J.; Chaignaud, B.; Vacanti, J.P. In Vitro Organogenesis of Liver Tissuea. Ann. N. Y. Acad. Sci. 1997, 831, 382-397. [CrossRef]

43. Wu, B.M.; Borland, S.W.; Giordano, R.A.; Cima, L.G.; Sachs, E.M.; Cima, M.J. Solid Free-Form Fabrication of Drug Delivery Devices. J. Control. Release 1996, 40, 77-87. [CrossRef]

44. Mandrycky, C.; Wang, Z.; Kim, K.; Kim, D.-H. 3D Bioprinting for Engineering Complex Tissues. Biotechnol. Adv. 2016, 34, 422-434. [CrossRef] [PubMed]

45. Xu, T.; Jin, J.; Gregory, C.; Hickman, J.J.J.J.; Boland, T. Inkjet Printing of Viable Mammalian Cells. Biomaterials 2005, 26, 93-99. [CrossRef] [PubMed]

46. Pepper, M.E.; Seshadri, V.; Burg, T.C.; Burg, K.J.L.; Groff, R.E. Characterizing the Effects of Cell Settling on Bioprinter Output. Biofabrication 2012, 4, 011001. [CrossRef] [PubMed]

47. Li, X.; Liu, B.; Pei, B.; Chen, J.; Zhou, D.; Peng, J.; Zhang, X.; Jia, W.; Xu, T. Inkjet Bioprinting of Biomaterials. Chem. Rev. 2020, 120, 10793-10833. [CrossRef]

48. Guillemot, F.; Souquet, A.; Catros, S.; Guillotin, B.; Lopez, J.; Faucon, M.; Pippenger, B.; Bareille, R.; Rémy, M.; Bellance, S.; et al. High-Throughput Laser Printing of Cells and Biomaterials for Tissue Engineering. Acta Biomater. 2010, 6, 2494-2500. [CrossRef]

49. Hakobyan, D.; Kerouredan, O.; Remy, M.; Dusserre, N.; Medina, C.; Devillard, R.; Fricain, J.-C.; Oliveira, H. Laser-Assisted Bioprinting for Bone Repair. In 3D Bioprinting: Principles and Protocols; Crook, J.M., Ed.; Springer US: New York, NY, USA, 2020; pp. 135-144. ISBN 978-1-07-160520-2.

50. Salah, M.; Tayebi, L.; Moharamzadeh, K.; Naini, F.B. Three-Dimensional Bio-Printing and Bone Tissue Engineering: Technical Innovations and Potential Applications in Maxillofacial Reconstructive Surgery. Maxillofac. Plast. Reconstr. Surg. $2020,42$. [CrossRef]

51. Osidak, E.O.; Kozhukhov, V.I.; Osidak, M.S.; Domogatsky, S.P. Collagen as Bioink for Bioprinting: A Comprehensive Review. Int. J. Bioprinting 2020, 6. [CrossRef]

52. Landers, R.; Mülhaupt, R. Desktop Manufacturing of Complex Objects, Prototypes and Biomedical Scaffolds by Means of Computer-Assisted Design Combined with Computer-Guided 3D Plotting of Polymers and Reactive Oligomers. Macromol. Mater. Eng. 2000, 282, 17-21. [CrossRef]

53. Maher, P.S.; Keatch, R.P.; Donnelly, K.; Paxton, J.Z. Formed 3D Bio-Scaffolds via Rapid Prototyping Technology. In Proceedings of the 4th European Conference of the International Federation for Medical and Biological Engineering, Antwerp, Belgium, 23-27 November 2008; Vander Sloten, J., Verdonck, P., Nyssen, M., Haueisen, J., Eds.; Springer: Berlin/Heidelberg, Germany, 2009; pp. 2200-2204.

54. Dowler, C. Automatic Model Building Cuts Design Time. Costs. Plast. Eng. 1989, 45, 43-45.

55. Arcaute, K.; Mann, B.K.; Wicker, R.B. Practical Use of Hydrogels in Stereolithography for Tissue Engineering Applications. In Stereolithography: Materials, Processes and Applications; Bártolo, P.J., Ed.; Springer US: Boston, MA, USA, 2011 ; pp. $299-331$. ISBN 978-0-387-92904-0.

56. Magalhães, L.S.S.; Santos, F.E.P.; Elias, C.D.M.V.; Afewerki, S.; Sousa, G.F.; Furtado, A.S.; Marciano, F.R.; Lobo, A.O. Printing 3D Hydrogel Structures Employing Low-Cost Stereolithography Technology. J. Funct. Biomater. 2020, 11, 12. [CrossRef] 
57. Jiao, Z.; Wang, C.; Yang, Q.; Wang, X. Preparation and Characterization of UV-Curable Urethane Acrylate Oligomers Modified with Cycloaliphatic Epoxide Resin. J. Coat. Technol. Res. 2018, 15, 251-258. [CrossRef]

58. Sangermano, M.; Carbonaro, W.; Malucelli, G.; Priola, A. UV-Cured Interpenetrating Acrylic-Epoxy Polymer Networks: Preparation and Characterization. Macromol. Mater. Eng. 2008, 293, 515-520. [CrossRef]

59. Hong, B.T.; Shin, K.S.; Kim, D.S. Ultraviolet-Curing Behavior of an Epoxy Acrylate Resin System. J. Appl. Polym. Sci. 2005, 98, 1180-1185. [CrossRef]

60. Lovell, L.G.; Lu, H.; Elliott, J.E.; Stansbury, J.W.; Bowman, C.N. The Effect of Cure Rate on the Mechanical Properties of Dental Resins. Dent. Mater. 2001, 17, 504-511. [CrossRef]

61. Chen, K.; Kuang, X.; Li, V.; Kang, G.; Jerry Qi, H. Fabrication of Tough Epoxy with Shape Memory Effects by UV-Assisted Direct-Ink Write Printing. Soft Matter. 2018, 14, 1879-1886. [CrossRef] [PubMed]

62. Zhang, Z.; Li, P.; Chu, F.; Shen, G. Influence of the Three-Dimensional Printing Technique and Printing Layer Thickness on Model Accuracy. J. Orofac. Orthop. Fortschritte Kieferorthopädie 2019, 80, 194-204. [CrossRef]

63. Watters, M.P.; Bernhardt, M.L. Curing Parameters to Improve the Mechanical Properties of Stereolithographic Printed Specimens Rapid Prototyp. J. 2018, 24, 46-51. [CrossRef]

64. Yankov, E.; Nikolova, M.P. Comparison of the Accuracy of 3D Printed Prototypes Using the Stereolithography (SLA) Method with the Digital CAD Models. In Proceedings of the MATEC Web of Conferences, Online, 9 August 2017; Volume 137, p. 02014. [CrossRef]

65. Van Noort, R. The Future of Dental Devices Is Digital. Dent. Mater. 2012, 28, 3-12. [CrossRef]

66. Pattanayak, D.K.; Fukuda, A.; Matsushita, T.; Takemoto, M.; Fujibayashi, S.; Sasaki, K.; Nishida, N.; Nakamura, T.; Kokubo, T. Bioactive Ti Metal Analogous to Human Cancellous Bone: Fabrication by Selective Laser Melting and Chemical Treatments. Acta Biomater. 2011, 7, 1398-1406. [CrossRef]

67. Lohfeld, S.; Tyndyk, M.A.; Cahill, S.; Flaherty, N.; Barron, V.; McHugh, P.E. A Method to Fabricate Small Features on Scaffolds for Tissue Engineering via Selective Laser Sintering. J. Biomed. Sci. Eng. 2010, 3, 138. [CrossRef]

68. Wunner, F.M.; Florczak, S.; Mieszczanek, P.; Bas, O.; De-Juan-Pardo, E.M.; Hutmacher, D.W. 5.13 Electrospinning with Polymer Melts-State of the Art and Future Perspectives. In Comprehensive Biomaterials II; Ducheyne, P., Ed.; Elsevier: Oxford, UK, 2017; pp. 217-235. ISBN 978-0-08-100692-4.

69. Dalton, P.D.; Grafahrend, D.; Klinkhammer, K.; Klee, D.; Möller, M. Electrospinning of Polymer Melts: Phenomenological Observations. Polymer 2007, 48, 6823-6833. [CrossRef]

70. Hochleitner, G.; Jüngst, T.; Brown, T.D.; Hahn, K.; Moseke, C.; Jakob, F.; Dalton, P.D.; Groll, J. Additive Manufacturing of Scaffolds with Sub-Micron Filaments via Melt Electrospinning Writing. Biofabrication 2015, 7, 035002. [CrossRef]

71. Narayanan, L.K.; Shirwaiker, R.A. Experimental Characterization and Finite Element Modeling of the Effects of 3D Bioplotting Process Parameters on Structural and Tensile Properties of Polycaprolactone (PCL) Scaffolds. Appl. Sci. 2020, 10, 5289. [CrossRef]

72. Rajabi, M.; McConnell, M.; Cabral, J.; Ali, M.A. Chitosan Hydrogels in 3D Printing for Biomedical Applications. Carbohydr. Polym. 2021, 260, 117768. [CrossRef]

73. Su, X.; Wang, T.; Guo, S. Applications of 3D Printed Bone Tissue Engineering Scaffolds in the Stem Cell Field. Regen. Ther. 2021, 16, 63-72. [CrossRef]

74. Guzzi, E.A.; Tibbitt, M.W. Additive Manufacturing of Precision Biomaterials. Adv. Mater. 2020, 32, 1901994. [CrossRef]

75. Zhang, H.; Cong, Y.; Osi, A.R.; Zhou, Y.; Huang, F.; Zaccaria, R.P.; Chen, J.; Wang, R.; Fu, J. Direct 3D Printed Biomimetic Scaffolds Based on Hydrogel Microparticles for Cell Spheroid Growth. Adv. Funct. Mater. 2020, 30, 1910573. [CrossRef]

76. Melocchi, A.; Briatico-Vangosa, F.; Uboldi, M.; Parietti, F.; Turchi, M.; von Zeppelin, D.; Maroni, A.; Zema, L.; Gazzaniga, A.; Zidan, A. Quality Considerations on the Pharmaceutical Applications of Fused Deposition Modeling 3D Printing. Int. J. Pharm. 2021, 592, 119901. [CrossRef]

77. Melocchi, A.; Uboldi, M.; Cerea, M.; Foppoli, A.; Maroni, A.; Moutaharrik, S.; Palugan, L.; Zema, L.; Gazzaniga, A. A Graphical Review on the Escalation of Fused Deposition Modeling (FDM) 3D Printing in the Pharmaceutical Field. J. Pharm. Sci. 2020, 109, 2943-2957. [CrossRef]

78. Choi, W.J.; Hwang, K.S.; Kwon, H.J.; Lee, C.; Kim, C.H.; Kim, T.H.; Heo, S.W.; Kim, J.-H.; Lee, J.-Y. Rapid Development of Dual Porous Poly(Lactic Acid) Foam Using Fused Deposition Modeling (FDM) 3D Printing for Medical Scaffold Application. Mater. Sci. Eng. C Mater. Biol. Appl. 2020, 110, 110693. [CrossRef]

79. Xiong, Z.; Liu, W.; Qian, H.; Lei, T.; He, X.; Hu, Y.; Lei, P. Tantalum Nanoparticles Reinforced PCL Scaffolds Using Direct 3D Printing for Bone Tissue Engineering. Front. Mater. 2021, 8. [CrossRef]

80. Casanova-Batlle, E.; Guerra, A.J.; Ciurana, J. Continuous Based Direct Ink Write for Tubular Cardiovascular Medical Devices. Polymers 2021, 13, 77. [CrossRef] [PubMed]

81. Gross, B.C.; Erkal, J.L.; Lockwood, S.Y.; Chen, C.; Spence, D.M. Evaluation of 3D Printing and Its Potential Impact on Biotechnology and the Chemical Sciences. Anal. Chem. 2014, 86, 3240-3253. [CrossRef] [PubMed]

82. Wong, K.V.; Hernandez, A. A Review of Additive Manufacturing. ISRN Mech. Eng. 2012, 2012, e208760. [CrossRef]

83. Awad, A.; Fina, F.; Goyanes, A.; Gaisford, S.; Basit, A.W. 3D Printing: Principles and Pharmaceutical Applications of Selective Laser Sintering. Int. J. Pharm. 2020, 586. [CrossRef] 
84. Riza, S.H.; Masood, S.H.; Rashid, R.A.R.; Chandra, S. 6-Selective laser sintering in biomedical manufacturing. In Metallic Biomaterials Processing and Medical Device Manufacturing; Woodhead Publishing Series in Biomaterials; Wen, C., Ed.; Woodhead Publishing: Cambridge, UK, 2020; pp. 193-233. ISBN 978-0-08-102965-7.

85. Salmi, M. Additive Manufacturing Processes in Medical Applications. Materials 2021, 14, 191. [CrossRef]

86. Lin, K.; Liu, J.; Wu, J.-M.; Sun, Y.; Li, F.; Zhou, Y.; Shi, Y. Selective Laser Sintered Nano-HA/PDLLA Composite Microspheres for Bone Scaffolds Applications. Rapid Prototyp. J. 2020, 26, 1131-1143. [CrossRef]

87. Qin, T.; Li, X.; Long, H.; Bin, S.; Xu, Y. Bioactive Tetracalcium Phosphate Scaffolds Fabricated by Selective Laser Sintering for Bone Regeneration Applications. Materials 2020, 13, 2268. [CrossRef]

88. Xu, X.; Goyanes, A.; Trenfield, S.J.; Diaz-Gomez, L.; Alvarez-Lorenzo, C.; Gaisford, S.; Basit, A.W. Stereolithography (SLA) 3D Printing of a Bladder Device for Intravesical Drug Delivery. Mater. Sci. Eng. C 2021, 120, 111773. [CrossRef]

89. Sun, W.; Starly, B.; Darling, A.; Gomez, C. Computer-aided Tissue Engineering: Application to Biomimetic Modelling and Design of Tissue Scaffolds. Biotechnol. Appl. Biochem. 2004, 39, 49-58. [CrossRef]

90. Giannitelli, S.M.; Accoto, D.; Trombetta, M.; Rainer, A. Current Trends in the Design of Scaffolds for Computer-Aided Tissue Engineering. Acta Biomater. 2014, 10, 580-594. [CrossRef]

91. Heljak, M.K.; Kurzydlowski, K.J.; Swieszkowski, W. Computer Aided Design of Architecture of Degradable Tissue Engineering Scaffolds. Comput. Methods Biomech. Biomed. Engin. 2017, 20, 1623-1632. [CrossRef]

92. Mahmood, M.A.; Visan, A.I.; Ristoscu, C.; Mihailescu, I.N. Artificial Neural Network Algorithms for 3D Printing. Materials 2021, 14, 163. [CrossRef]

93. Conev, A.; Litsa, E.E.; Perez, M.R.; Diba, M.; Mikos, A.G.; Kavraki, L.E. Machine Learning-Guided Three-Dimensional Printing of Tissue Engineering Scaffolds. Tissue Eng. Part A 2020, 26, 1359-1368. [CrossRef]

94. Ng, W.L.; Chan, A.; Ong, Y.S.; Chua, C.K. Deep Learning for Fabrication and Maturation of 3D Bioprinted Tissues and Organs. Virtual Phys. Prototyp. 2020, 15, 340-358. [CrossRef]

95. Dhandayuthapani, B.; Yoshida, Y.; Maekawa, T.; Kumar, D.S. Polymeric Scaffolds in Tissue Engineering Application: A Review. Int. J. Polym. Sci. 2011, 2011, e290602. [CrossRef]

96. Hölzl, K.; Lin, S.; Tytgat, L.; Vlierberghe, S.V.; Gu, L.; Ovsianikov, A. Bioink Properties before, during and after 3D Bioprinting. Biofabrication 2016, 8, 032002. [CrossRef]

97. Andersson, J.; Stenhamre, H.; Bäckdahl, H.; Gatenholm, P. Behavior of Human Chondrocytes in Engineered Porous Bacterial Cellulose Scaffolds. J. Biomed. Mater. Res. A 2010, 94A, 1124-1132. [CrossRef]

98. Jia, M.A.; Zhao, Y.; Liu, L.; Qin, H.; Li, M. A Study on the Chondrogenesis of Collagen Gel Containing Rapid Prototyping PLGA and Chon-Drocytes in Vivo. J. Pract. Stomatol. 2009, 25, 9-12.

99. Yan, Q.; Dong, H.; Su, J.; Han, J.; Song, B.; Wei, Q.; Shi, Y. A Review of 3D Printing Technology for Medical Applications. Engineering 2018, 4, 729-742. [CrossRef]

100. Kołbuk, D.; Heljak, M.; Choińska, E.; Urbanek, O. Novel 3D Hybrid Nanofiber Scaffolds for Bone Regeneration. Polymers 2020, 12, 544. [CrossRef] [PubMed]

101. Huang, J.; Huang, Z.; Liang, Y.; Yuan, W.; Bian, L.; Duan, L.; Rong, Z.; Xiong, J.; Wang, D.; Xia, J. 3D Printed Gelatin/Hydroxyapatite Scaffolds for Stem Cell Chondrogenic Differentiation and Articular Cartilage Repair. Biomater. Sci. 2021, 9, 2620-2630. [CrossRef]

102. Graham, A.D.; Olof, S.N.; Burke, M.J.; Armstrong, J.P.K.; Mikhailova, E.A.; Nicholson, J.G.; Box, S.J.; Szele, F.G.; Perriman, A.W.; Bayley, H. High-Resolution Patterned Cellular Constructs by Droplet-Based 3D Printing. Sci. Rep. 2017, 7, 7004. [CrossRef]

103. Zwawi, M. A Review on Natural Fiber Bio-Composites, Surface Modifications and Applications. Molecules 2021, $26,404$. [CrossRef] [PubMed]

104. Garot, C.; Bettega, G.; Picart, C. Additive Manufacturing of Material Scaffolds for Bone Regeneration: Toward Application in the Clinics. Adv. Funct. Mater. 2020, 31. [CrossRef] [PubMed]

105. Top, N.; Şahin, İ; Gökçe, H.; Gökçe, H. Computer-Aided Design and Additive Manufacturing of Bone Scaffolds for Tissue Engineering: State of the Art. J. Mater. Res. 2021, 2044-5326. [CrossRef]

106. Intra, J.; Salem, A.K. Characterization of the Transgene Expression Generated by Branched and Linear Polyethylenimine-Plasmid DNA Nanoparticles in Vitro and after Intraperitoneal Injection in Vivo. J. Control. Release Off. J. Control. Release Soc. 2008, 130, 129-138. [CrossRef] [PubMed]

107. Rajan, V.; Murray, R. The Duplicitous Nature of Inflammation in Wound Repair. Wound Pract. Res. 2008, 16, 122-129.

108. Sung, H.-J.; Meredith, C.; Johnson, C.; Galis, Z.S. The Effect of Scaffold Degradation Rate on Three-Dimensional Cell Growth and Angiogenesis. Biomaterials 2004, 25, 5735-5742. [CrossRef] [PubMed]

109. Park, S.H.; Park, D.S.; Shin, J.W.; Kang, Y.G.; Kim, H.K.; Yoon, T.R.; Shin, J.-W. Scaffolds for Bone Tissue Engineering Fabricated from Two Different Materials by the Rapid Prototyping Technique: PCL versus PLGA. J. Mater. Sci. Mater. Med. 2012, 23, 2671-2678. [CrossRef]

110. Ma, P.X. Scaffolds for Tissue Fabrication. Mater. Today 2004, 7, 30-40. [CrossRef]

111. Oryan, A.; Kamali, A.; Moshiri, A.; Baghaban Eslaminejad, M. Role of Mesenchymal Stem Cells in Bone Regenerative Medicine: What Is the Evidence? Cells Tissues Organs 2017, 204, 59-83. [CrossRef]

112. Aydin, A.; Memisoglu, K.; Cengiz, A.; Atmaca, H.; Muezzinoglu, B.; Muezzinoglu, U.S. Effects of Botulinum Toxin A on Fracture Healing in Rats: An Experimental Study. J. Orthop. Sci. Off. J. Jpn. Orthop. Assoc. 2012, 17, 796-801. [CrossRef] 
113. Xu, T.; Binder, K.W.; Albanna, M.Z.; Dice, D.; Zhao, W.; Yoo, J.J.; Atala, A. Hybrid Printing of Mechanically and Biologically Improved Constructs for Cartilage Tissue Engineering Applications. Biofabrication 2013, 5, 015001. [CrossRef]

114. Heljak, M.K.; Moczulska-Heljak, M.; Choińska, E.; Chlanda, A.; Kosik-Kozioł, A.; Jaroszewicz, T.; Jaroszewicz, J.; Swieszkowski, W. Micro and Nanoscale Characterization of Poly(DL-Lactic-Co-Glycolic Acid) Films Subjected to the L929 Cells and the Cyclic Mechanical Load. Micron 2018, 115, 64-72. [CrossRef]

115. Kim, S.S.; Utsunomiya, H.; Koski, J.A.; Wu, B.M.; Cima, M.J.; Sohn, J.; Mukai, K.; Griffith, L.G.; Vacanti, J.P. Survival and Function of Hepatocytes on a Novel Three-Dimensional Synthetic Biodegradable Polymer Scaffold with an Intrinsic Network of Channels. Ann. Surg. 1998, 228, 8-13. [CrossRef]

116. Gong, C.; Shi, S.; Dong, P.; Kan, B.; Gou, M.; Wang, X.; Li, X.; Luo, F.; Zhao, X.; Wei, Y.; et al. Synthesis and Characterization of PEG-PCL-PEG Thermosensitive Hydrogel. Int. J. Pharm. 2009, 365, 89-99. [CrossRef]

117. Choi, S.H.; Park, T.G. Synthesis and Characterization of Elastic PLGA/PCL/PLGA Tri-Block Copolymers. J. Biomater. Sci. Polym. Ed. 2002, 13, 1163-1173. [CrossRef]

118. Frone, A.N.; Batalu, D.; Chiulan, I.; Oprea, M.; Gabor, A.R.; Nicolae, C.-A.; Raditoiu, V.; Trusca, R.; Panaitescu, D.M. MorphoStructural, Thermal and Mechanical Properties of PLA/PHB/Cellulose Biodegradable Nanocomposites Obtained by Compression Molding, Extrusion, and 3D Printing. Nanomaterials 2020, 10, 51. [CrossRef]

119. Koons, G.L.; Kontoyiannis, P.D.; Diba, M.; Chim, L.K.; Scott, D.W.; Mikos, A.G. Effect of 3D Printing Temperature on Bioactivity of Bone Morphogenetic Protein-2 Released from Polymeric Constructs. Ann. Biomed. Eng. 2021, 1-12. [CrossRef]

120. Suo, H.; Zhang, J.; Xu, M.; Wang, L. Low-Temperature 3D Printing of Collagen and Chitosan Composite for Tissue Engineering. Mater. Sci. Eng. C 2021, 123, 111963. [CrossRef] [PubMed]

121. Daly, A.C.; Cunniffe, G.M.; Sathy, B.N.; Jeon, O.; Alsberg, E.; Kelly, D.J. 3D Bioprinting of Developmentally Inspired Templates for Whole Bone Organ Engineering. Adv. Healthc. Mater. 2016, 5, 2353-2362. [CrossRef]

122. Park, J.Y.; Shim, J.-H.; Choi, S.-A.; Jang, J.; Kim, M.; Lee, S.H.; Cho, D.-W. 3D Printing Technology to Control BMP-2 and VEGF Delivery Spatially and Temporally to Promote Large-Volume Bone Regeneration. J. Mater. Chem. B 2015, 3, 5415-5425. [CrossRef]

123. Shim, J.-H.; Jang, K.-M.; Hahn, S.K.; Park, J.Y.; Jung, H.; Oh, K.; Park, K.M.; Yeom, J.; Park, S.H.; Kim, S.W.; et al. ThreeDimensional Bioprinting of Multilayered Constructs Containing Human Mesenchymal Stromal Cells for Osteochondral Tissue Regeneration in the Rabbit Knee Joint. Biofabrication 2016, 8, 014102. [CrossRef]

124. Niemczyk, B.; Sajkiewicz, P.; Kolbuk, D. Injectable Hydrogels as Novel Materials for Central Nervous System Regeneration. J. Neural Eng. 2018, 15, 051002. [CrossRef]

125. Jeznach, O.; Kołbuk, D.; Sajkiewicz, P. Injectable Hydrogels and Nanocomposite Hydrogels for Cartilage Regeneration. J. Biomed. Mater. Res. A 2018, 106, 2762-2776. [CrossRef]

126. Billiet, T.; Gevaert, E.; De Schryver, T.; Cornelissen, M.; Dubruel, P. The 3D Printing of Gelatin Methacrylamide Cell-Laden Tissue-Engineered Constructs with High Cell Viability. Biomaterials 2014, 35, 49-62. [CrossRef]

127. Hribar, K.C.; Soman, P.; Warner, J.; Chung, P.; Chen, S. Light-Assisted Direct-Write of 3D Functional Biomaterials. Lab Chip 2013, 14, 268-275. [CrossRef]

128. Hosseini, V.; Ahadian, S.; Ostrovidov, S.; Camci-Unal, G.; Chen, S.; Kaji, H.; Ramalingam, M.; Khademhosseini, A. Engineered Contractile Skeletal Muscle Tissue on a Microgrooved Methacrylated Gelatin Substrate. Tissue Eng. Part A 2012, 18, $2453-2465$. [CrossRef]

129. Perez, D.; Silva, J.; Lunz, C.; Fernandes, E.R.; Oliveira, G.E.; Francisco, E.; Jesus, O. Poly (Butylene Succinate) Scaffolds Prepared by Leaching. Polym. Sci. 2017, 1, 210-212. [CrossRef]

130. Pati, F.; Jang, J.; Ha, D.-H.; Won Kim, S.; Rhie, J.-W.; Shim, J.-H.; Kim, D.-H.; Cho, D.-W. Printing Three-Dimensional Tissue Analogues with Decellularized Extracellular Matrix Bioink. Nat. Commun. 2014, 5, 3935. [CrossRef] [PubMed]

131. Hutmacher, D.W.; Schantz, T.; Zein, I.; Ng, K.W.; Teoh, S.H.; Tan, K.C. Mechanical Properties and Cell Cultural Response of Polycaprolactone Scaffolds Designed and Fabricated via Fused Deposition Modeling. J. Biomed. Mater. Res. 2001, 55, $203-216$. [CrossRef]

132. Bari, E.; Scocozza, F.; Perteghella, S.; Sorlini, M.; Auricchio, F.; Torre, M.L.; Conti, M. 3D Bioprinted Scaffolds Containing Mesenchymal Stem/Stromal Lyosecretome: Next Generation Controlled Release Device for Bone Regenerative Medicine. Pharmaceutics 2021, 13, 515. [CrossRef]

133. Patrício, T.; Domingos, M.; Gloria, A.; Bártolo, P. Characterisation of PCL and PCL/PLA Scaffolds for Tissue Engineering. Procedia CIRP 2013, 5, 110-114. [CrossRef]

134. Dong, L.; Wang, S.-J.; Zhao, X.-R.; Zhu, Y.-F.; Yu, J.-K. 3D- Printed Poly(ع-Caprolactone) Scaffold Integrated with Cell-Laden Chitosan Hydrogels for Bone Tissue Engineering. Sci. Rep. 2017, 7, 13412. [CrossRef]

135. Jiao, Z.; Luo, B.; Xiang, S.; Ma, H.; Yu, Y.; Yang, W. 3D Printing of HA/PCL Composite Tissue Engineering Scaffolds. Adv. Ind. Eng. Polym. Res. 2019, 2, 196-202. [CrossRef]

136. Vyas, C.; Zhang, J.; Øvrebø, Ø.; Huang, B.; Roberts, I.; Setty, M.; Allardyce, B.; Haugen, H.; Rajkhowa, R.; Bartolo, P. 3D Printing of Silk Microparticle Reinforced Polycaprolactone Scaffolds for Tissue Engineering Applications. Mater. Sci. Eng. C 2021, 118, 111433. [CrossRef] [PubMed]

137. Miao, S.; Zhu, W.; Castro, N.J.; Leng, J.; Zhang, L.G. Four-Dimensional Printing Hierarchy Scaffolds with Highly Biocompatible Smart Polymers for Tissue Engineering Applications. Tissue Eng. Part C Methods 2016, 22, 952-963. [CrossRef] 
138. Mellor, L.F.; Huebner, P.; Cai, S.; Mohiti-Asli, M.; Taylor, M.A.; Spang, J.; Shirwaiker, R.A.; Loboa, E.G. Fabrication and Evaluation of Electrospun, 3D-Bioplotted, and Combination of Electrospun/3D-Bioplotted Scaffolds for Tissue Engineering Applications. BioMed Res. Int. 2017, 2017, 6956794. [CrossRef]

139. Doyle, S.E.; Henry, L.; McGennisken, E.; Onofrillo, C.; Bella, C.D.; Duchi, S.; O'Connell, C.D.; Pirogova, E. Characterization of Polycaprolactone Nanohydroxyapatite Composites with Tunable Degradability Suitable for Indirect Printing. Polymers 2021, 13, 295. [CrossRef]

140. Fox, K.; Ratwatte, R.; Booth, M.A.; Tran, H.M.; Tran, P.A. High Nanodiamond Content-PCL Composite for Tissue Engineering Scaffolds. Nanomaterials 2020, 10, 948. [CrossRef] [PubMed]

141. Chou, Y.-C.; Yeh, W.-L.; Chao, C.-L.; Hsu, Y.-H.; Yu, Y.-H.; Chen, J.-K.; Liu, S.-J. Enhancement of Tendon-Bone Healing via the Combination of Biodegradable Collagen-Loaded Nanofibrous Membranes and a Three-Dimensional Printed Bone-Anchoring Bolt. Int. J. Nanomed. 2016, 11, 4173-4186. [CrossRef]

142. Ritz, U.; Gerke, R.; Götz, H.; Stein, S.; Rommens, P.M. A New Bone Substitute Developed from 3D-Prints of Polylactide (PLA) Loaded with Collagen I: An In Vitro Study. Int. J. Mol. Sci. 2017, 18, 2569. [CrossRef]

143. Holmes, B.; Zhu, W.; Li, J.; Lee, J.D.; Zhang, L.G. Development of Novel Three-Dimensional Printed Scaffolds for Osteochondral Regeneration. Tissue Eng. Part A 2015, 21, 403-415. [CrossRef]

144. Tan, Y.J.; Tan, X.; Yeong, W.Y.; Tor, S.B. Additive Manufacturing of Patient-Customizable Scaffolds for Tubular Tissues Using the Melt-Drawing Method. Materials 2016, 9, 893. [CrossRef]

145. Rosenzweig, D.H.; Carelli, E.; Steffen, T.; Jarzem, P.; Haglund, L. 3D-Printed ABS and PLA Scaffolds for Cartilage and Nucleus Pulposus Tissue Regeneration. Int. J. Mol. Sci. 2015, 16, 15118-15135. [CrossRef]

146. Gregor, A.; Filová, E.; Novák, M.; Kronek, J.; Chlup, H.; Buzgo, M.; Blahnová, V.; Lukášová, V.; Bartoš, M.; Nečas, A.; et al. Designing of PLA Scaffolds for Bone Tissue Replacement Fabricated by Ordinary Commercial 3D Printer. J. Biol. Eng. 2017, 11, 31. [CrossRef]

147. Feng, C.; Zhou, J.; Xu, X.; Jiang, Y.; Shi, H.; Zhao, G. Performance Study of Grass-Derived Nano-Cellulose and Polycaprolactone Composites for 3D Printing. Appl. Sci. 2021, 11, 1273. [CrossRef]

148. Shim, J.-H.; Kim, S.E.; Park, J.Y.; Kundu, J.; Kim, S.W.; Kang, S.S.; Cho, D.-W. Three-Dimensional Printing of RhBMP-2-Loaded Scaffolds with Long-Term Delivery for Enhanced Bone Regeneration in a Rabbit Diaphyseal Defect. Tissue Eng. Part A 2014, 20, 1980-1992. [CrossRef]

149. Lee, S.; Lee, H.S.; Chung, J.J.; Kim, S.H.; Park, J.W.; Lee, K.; Jung, Y. Enhanced Regeneration of Vascularized Adipose Tissue with Dual 3D-Printed Elastic Polymer/DECM Hydrogel Complex. Int. J. Mol. Sci. 2021, 22, 2886. [CrossRef]

150. Hong, S.; Sycks, D.; Chan, H.F.; Lin, S.; Lopez, G.P.; Guilak, F.; Leong, K.W.; Zhao, X. 3D Printing of Highly Stretchable and Tough Hydrogels into Complex, Cellularized Structures. Adv. Mater. 2015, 27, 4035-4040. [CrossRef] [PubMed]

151. Williams, S.K.; Touroo, J.S.; Church, K.H.; Hoying, J.B. Encapsulation of Adipose Stromal Vascular Fraction Cells in Alginate Hydrogel Spheroids Using a Direct-Write Three-Dimensional Printing System. BioResearch 2013, 2, 448-454. [CrossRef]

152. Yang, X.; Lu, Z.; Wu, H.; Li, W.; Zheng, L.; Zhao, J. Collagen-Alginate as Bioink for Three-Dimensional (3D) Cell Printing Based Cartilage Tissue Engineering. Mater. Sci. Eng. C Mater. Biol. Appl. 2018, 83, 195-201. [CrossRef] [PubMed]

153. Jiang, T.; Munguia-Lopez, J.G.; Flores-Torres, S.; Grant, J.; Vijayakumar, S.; Leon-Rodriguez, A.D.; Kinsella, J.M. Directing the Self-Assembly of Tumour Spheroids by Bioprinting Cellular Heterogeneous Models within Alginate/Gelatin Hydrogels. Sci. Rep. 2017, 7, 4575. [CrossRef] [PubMed]

154. Jia, W.; Gungor-Ozkerim, P.S.; Zhang, Y.S.; Yue, K.; Zhu, K.; Liu, W.; Pi, Q.; Byambaa, B.; Dokmeci, M.R.; Shin, S.R.; et al. Direct 3D Bioprinting of Perfusable Vascular Constructs Using a Blend Bioink. Biomaterials 2016, 106, 58-68. [CrossRef] [PubMed]

155. Maia-Pinto, M.O.C.; Brochado, A.C.B.; Teixeira, B.N.; Sartoretto, S.C.; Uzeda, M.J.; Alves, A.T.N.N.; Alves, G.G.; Calasans-Maia, M.D.; Thiré, R.M.S.M. Biomimetic Mineralization on 3d Printed Pla Scaffolds: On the Response of Human Primary Osteoblasts Spheroids and in Vivo Implantation. Polymers 2021, 13, 74. [CrossRef]

156. Posa, F.; Di Benedetto, A.; Ravagnan, G.; Cavalcanti-Adam, E.A.; Lo Muzio, L.; Percoco, G.; Mori, G. Bioengineering Bone Tissue with 3D Printed Scaffolds in the Presence of Oligostilbenes. Materials 2020, 13, 4471. [CrossRef]

157. Duan, B.; Kapetanovic, E.; Hockaday, L.A.; Butcher, J.T. Three-Dimensional Printed Trileaflet Valve Conduits Using Biological Hydrogels and Human Valve Interstitial Cells. Acta Biomater. 2014, 10, 1836-1846. [CrossRef]

158. Poldervaart, M.T.; Goversen, B.; de Ruijter, M.; Abbadessa, A.; Melchels, F.P.W.; Öner, F.C.; Dhert, W.J.A.; Vermonden, T.; Alblas, J. 3D Bioprinting of Methacrylated Hyaluronic Acid (MeHA) Hydrogel with Intrinsic Osteogenicity. PLoS ONE 2017, 12, e0177628. [CrossRef]

159. Nadernezhad, A.; Khani, N.; Skvortsov, G.A.; Toprakhisar, B.; Bakirci, E.; Menceloglu, Y.; Unal, S.; Koc, B. Multifunctional 3D Printing of Heterogeneous Hydrogel Structures. Sci. Rep. 2016, 6, 33178. [CrossRef]

160. Tan, Z.; Parisi, C.; Di Silvio, L.; Dini, D.; Forte, A.E. Cryogenic 3D Printing of Super Soft Hydrogels. Sci. Rep. 2017, 7, 16293. [CrossRef]

161. Xia, Y.; Xue, B.; Qin, M.; Cao, Y.; Li, Y.; Wang, W. Printable Fluorescent Hydrogels Based on Self-Assembling Peptides. Sci. Rep. 2017, 7, 9691. [CrossRef]

162. Gaetani, R.; Feyen, D.A.M.; Verhage, V.; Slaats, R.; Messina, E.; Christman, K.L.; Giacomello, A.; Doevendans, P.A.F.M.; Sluijter, J.P.G. Epicardial Application of Cardiac Progenitor Cells in a 3D-Printed Gelatin/Hyaluronic Acid Patch Preserves Cardiac Function after Myocardial Infarction. Biomaterials 2015, 61, 339-348. [CrossRef] 
163. Fu, F.; Qin, Z.; Xu, C.; Chen, X.; Li, R.; Wang, L.; Peng, D.; Sun, H.; Tu, Y.; Chen, C.; et al. Magnetic Resonance Imaging-ThreeDimensional Printing Technology Fabricates Customized Scaffolds for Brain Tissue Engineering. Neural Regen. Res. 2017, 12, 614-622. [CrossRef]

164. Dai, X.; Liu, L.; Ouyang, J.; Li, X.; Zhang, X.; Lan, Q.; Xu, T. Coaxial 3D Bioprinting of Self-Assembled Multicellular Heterogeneous Tumor Fibers. Sci. Rep. 2017, 7, 1457. [CrossRef]

165. Suntornnond, R.; Tan, E.Y.S.; An, J.; Chua, C.K. A Highly Printable and Biocompatible Hydrogel Composite for Direct Printing of Soft and Perfusable Vasculature-like Structures. Sci. Rep. 2017, 7, 16902. [CrossRef]

166. Kim, Y.; Kang, K.; Jeong, J.; Paik, S.S.; Kim, J.S.; Park, S.A.; Kim, W.D.; Park, J.; Choi, D. Three-Dimensional (3D) Printing of Mouse Primary Hepatocytes to Generate 3D Hepatic Structure. Ann. Surg. Treat. Res. 2017, 92, 67-72. [CrossRef]

167. Nguyen, D.; Hägg, D.A.; Forsman, A.; Ekholm, J.; Nimkingratana, P.; Brantsing, C.; Kalogeropoulos, T.; Zaunz, S.; Concaro, S.; Brittberg, M.; et al. Cartilage Tissue Engineering by the 3D Bioprinting of IPS Cells in a Nanocellulose/Alginate Bioink. Sci. Rep. 2017, 7. [CrossRef]

168. Möller, T.; Amoroso, M.; Hägg, D.; Brantsing, C.; Rotter, N.; Apelgren, P.; Lindahl, A.; Kölby, L.; Gatenholm, P. In Vivo Chondrogenesis in 3D Bioprinted Human Cell-Laden Hydrogel Constructs. Plast. Reconstr. Surg. Glob. Open 2017, 5. [CrossRef]

169. Zhang, X.; Zhang, Y. Tissue engineering applications of three-dimensional bioprinting. Cell Biochem. Biophys. 2015, 72, 777-782. [CrossRef]

170. Lee, S.J.; Lee, J.H.; Park, J.; Kim, W.D.; Park, S.A. Fabrication of 3D Printing Scaffold with Porcine Skin Decellularized Bio-Ink for Soft Tissue Engineering. Materials 2020, 13, 3522. [CrossRef] [PubMed]

171. Castro, N.J.; O'Brien, J.; Zhang, L.G. Integrating Biologically Inspired Nanomaterials and Table-Top Stereolithography for 3D Printed Biomimetic Osteochondral Scaffolds. Nanoscale 2015, 7, 14010-14022. [CrossRef]

172. Thunsiri, K.; Pitjamit, S.; Pothacharoen, P.; Pruksakorn, D.; Nakkiew, W.; Wattanutchariya, W. The 3D-Printed Bilayer's BioactiveBiomaterials Scaffold for Full-Thickness Articular Cartilage Defects Treatment. Materials 2020, 13, 3417. [CrossRef]

173. Gou, M.; Qu, X.; Zhu, W.; Xiang, M.; Yang, J.; Zhang, K.; Wei, Y.; Chen, S. Bio-Inspired Detoxification Using 3D-Printed Hydrogel Nanocomposites. Nat. Commun. 2014, 5, 3774. [CrossRef] [PubMed]

174. Russmueller, G.; Liska, R.; Stampfl, J.; Heller, C.; Mautner, A.; Macfelda, K.; Kapeller, B.; Lieber, R.; Haider, A.; Mika, K.; et al. 3D Printable Biophotopolymers for in Vivo Bone Regeneration. Materials 2015, 8, 3685-3700. [CrossRef]

175. Li, V.C.-F.; Dunn, C.K.; Zhang, Z.; Deng, Y.; Qi, H.J. Direct Ink Write (DIW) 3D Printed Cellulose Nanocrystal Aerogel Structures. Sci. Rep. 2017, 7, 8018. [CrossRef] [PubMed]

176. Seitz, H.; Rieder, W.; Irsen, S.; Leukers, B.; Tille, C. Three-Dimensional Printing of Porous Ceramic Scaffolds for Bone Tissue Engineering. J. Biomed. Mater. Res. B Appl. Biomater. 2005, 74, 782-788. [CrossRef] [PubMed]

177. Wu, C.; Fan, W.; Zhou, Y.; Luo, Y.; Gelinsky, M.; Chang, J.; Xiao, Y. 3D-Printing of Highly Uniform CaSiO3 Ceramic Scaffolds: Preparation, Characterization and in Vivo Osteogenesis. J. Mater. Chem. 2012, 22, 12288-12295. [CrossRef]

178. Roy, D.M.; Linnehan, S.K. Hydroxyapatite Formed from Coral Skeletal Carbonate by Hydrothermal Exchange. Nature 1974, 247, 220-222. [CrossRef]

179. Do, A.-V.; Khorsand, B.; Geary, S.M.; Salem, A.K. 3D Printing of Scaffolds for Tissue Regeneration Applications. Adv. Healthc. Mater. 2015, 4, 1742-1762. [CrossRef]

180. Roohani-Esfahani, S.-I.; Newman, P.; Zreiqat, H. Design and Fabrication of 3D Printed Scaffolds with a Mechanical Strength Comparable to Cortical Bone to Repair Large Bone Defects. Sci. Rep. 2016, 6, 19468. [CrossRef]

181. Özcan, M.; Hotza, D.; Fredel, M.C.; Cruz, A.; Volpato, C.A.M. Materials and Manufacturing Techniques for Polymeric and Ceramic Scaffolds Used in Implant Dentistry. J. Compos. Sci. 2021, 5, 78. [CrossRef]

182. Hua, L.; Lei, T.; Qian, H.; Zhang, Y.; Hu, Y.; Lei, P. 3D-Printed Porous Tantalum: Recent Application in Various Drug Delivery Systems to Repair Hard Tissue Defects. Expert Opin. Drug Deliv. 2021, 1-10. [CrossRef]

183. Ma, H.; Feng, C.; Chang, J.; Wu, C. 3D-Printed Bioceramic Scaffolds: From Bone Tissue Engineering to Tumor Therapy. Acta Biomater. 2018, 79, 37-59. [CrossRef]

184. Gao, C.; Deng, Y.; Feng, P.; Mao, Z.; Li, P.; Yang, B.; Deng, J.; Cao, Y.; Shuai, C.; Peng, S. Current Progress in Bioactive Ceramic Scaffolds for Bone Repair and Regeneration. Int. J. Mol. Sci. 2014, 15, 4714-4732. [CrossRef]

185. Tarafder, S.; Bose, S. Polycaprolactone-Coated 3D Printed Tricalcium Phosphate Scaffolds for Bone Tissue Engineering: In Vitro Alendronate Release Behavior and Local Delivery Effect on in Vivo Osteogenesis. ACS Appl. Mater. Interfaces 2014, 6, $9955-9965$. [CrossRef]

186. Kim, J.-W.; Yang, B.-E.; Hong, S.-J.; Choi, H.-G.; Byeon, S.-J.; Lim, H.-K.; Chung, S.-M.; Lee, J.-H.; Byun, S.-H. Bone Regeneration Capability of 3D Printed Ceramic Scaffolds. Int. J. Mol. Sci. 2020, 21, 4837. [CrossRef]

187. Hwang, K.-S.; Choi, J.-W.; Kim, J.-H.; Chung, H.Y.; Jin, S.; Shim, J.-H.; Yun, W.-S.; Jeong, C.-M.; Huh, J.-B. Comparative Efficacies of Collagen-Based 3D Printed PCL/PLGA/ $\beta$-TCP Composite Block Bone Grafts and Biphasic Calcium Phosphate Bone Substitute for Bone Regeneration. Materials 2017, 10, 421. [CrossRef] [PubMed]

188. Zhang, W.; Lian, Q.; Li, D.; Wang, K.; Hao, D.; Bian, W.; He, J.; Jin, Z. Cartilage Repair and Subchondral Bone Migration Using 3D Printing Osteochondral Composites: A One-Year-Period Study in Rabbit Trochlea. BioMed Res. Int. 2014, 2014, e746138. [CrossRef]

189. Hodásová, L.; Sans, J.; Molina, B.G.; Alemán, C.; Llanes, L.; Fargas, G.; Armelin, E. Polymer Infiltrated Ceramic Networks with Biocompatible Adhesive and 3D-Printed Highly Porous Scaffolds. Addit. Manuf. 2021, 39, 101850. [CrossRef] 
190. Zhang, H.; Mao, X.; Du, Z.; Jiang, W.; Han, X.; Zhao, D.; Han, D.; Li, Q. Three Dimensional Printed Macroporous Polylactic Acid/Hydroxyapatite Composite Scaffolds for Promoting Bone Formation in a Critical-Size Rat Calvarial Defect Model. Sci. Technol. Adv. Mater. 2016, 17, 136-148. [CrossRef] [PubMed]

191. Zhang, H.; Mao, X.; Zhao, D.; Jiang, W.; Du, Z.; Li, Q.; Jiang, C.; Han, D. Three Dimensional Printed Polylactic AcidHydroxyapatite Composite Scaffolds for Prefabricating Vascularized Tissue Engineered Bone: An in Vivo Bioreactor Model. Sci. Rep. 2017, 7, 15255. [CrossRef] [PubMed]

192. Shor, L.; Güçeri, S.; Wen, X.; Gandhi, M.; Sun, W. Fabrication of Three-Dimensional Polycaprolactone/Hydroxyapatite Tissue Scaffolds and Osteoblast-Scaffold Interactions in Vitro. Biomaterials 2007, 28, 5291-5297. [CrossRef] [PubMed]

193. Zheng, P.; Yao, Q.; Mao, F.; Liu, N.; Xu, Y.; Wei, B.; Wang, L. Adhesion, Proliferation and Osteogenic Differentiation of

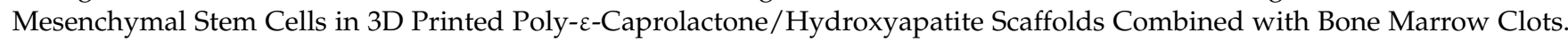
Mol. Med. Rep. 2017, 16, 5078-5084. [CrossRef]

194. Lee, C.H.; Hajibandeh, J.; Suzuki, T.; Fan, A.; Shang, P.; Mao, J.J. Three-Dimensional Printed Multiphase Scaffolds for Regeneration of Periodontium Complex. Tissue Eng. Part A 2014, 20, 1342-1351. [CrossRef]

195. Alluri, R.; Jakus, A.; Bougioukli, S.; Pannell, W.; Sugiyama, O.; Tang, A.; Shah, R.; Lieberman, J.R. 3D Printed Hyperelastic "Bone" Scaffolds and Regional Gene Therapy: A Novel Approach to Bone Healing. J. Biomed. Mater. Res. A 2018, 106, 1104-1110. [CrossRef]

196. Annis, D.S.; Mosher, D.F.; Roberts, D.D. 3D Printing of Composite Calcium Phospahte and Collagen Scaffolds for Bone Regeneration. Biomaterials 2014, 35. [CrossRef]

197. Yang, F.; Chen, C.; Zhou, Q.; Gong, Y.; Li, R.; Li, C.; Klämpfl, F.; Freund, S.; Wu, X.; Sun, Y.; et al. Laser Beam Melting 3D Printing of Ti6Al4V Based Porous Structured Dental Implants: Fabrication, Biocompatibility Analysis and Photoelastic Study. Sci. Rep. 2017, 7, 45360. [CrossRef]

198. Portan, D.V.; Ntoulias, C.; Mantzouranis, G.; Fortis, A.P.; Deligianni, D.D.; Polyzos, D.; Kostopoulos, V. Gradient 3D Printed PLA Scaffolds on Biomedical Titanium: Mechanical Evaluation and Biocompatibility. Polymers 2021, 13, 682. [CrossRef]

199. Li, C.; Jiang, C.; Deng, Y.; Li, T.; Li, N.; Peng, M.; Wang, J. RhBMP-2 Loaded 3D-Printed Mesoporous Silica/Calcium Phosphate Cement Porous Scaffolds with Enhanced Vascularization and Osteogenesis Properties. Sci. Rep. 2017, 7. [CrossRef]

200. Zhu, W.; Xu, C.; Ma, B.-P.; Zheng, Z.-B.; Li, Y.-L.; Ma, Q.; Wu, G.-L.; Weng, X.-S. Three-Dimensional Printed Scaffolds with Gelatin and Platelets Enhance In Vitro Preosteoblast Growth Behavior and the Sustained-Release Effect of Growth Factors. Chin. Med. J. 2016, 129, 2576-2581. [CrossRef]

201. Moussa, M.; Carrel, J.-P.; Scherrer, S.; Cattani-Lorente, M.; Wiskott, A.; Durual, S. Medium-Term Function of a 3D Printed TCP/HA Structure as a New Osteoconductive Scaffold for Vertical Bone Augmentation: A Simulation by BMP-2 Activation. Materials 2015, 8, 2174-2190. [CrossRef]

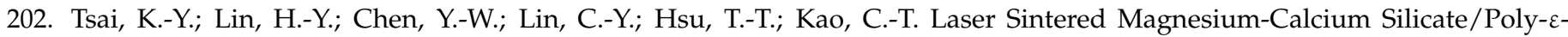
Caprolactone Scaffold for Bone Tissue Engineering. Materials 2017, 10, 65. [CrossRef]

203. Qi, X.; Pei, P.; Zhu, M.; Du, X.; Xin, C.; Zhao, S.; Li, X.; Zhu, Y. Three Dimensional Printing of Calcium Sulfate and Mesoporous Bioactive Glass Scaffolds for Improving Bone Regeneration in Vitro and in Vivo. Sci. Rep. 2017, 7, 42556. [CrossRef]

204. Sun, M.; Liu, A.; Shao, H.; Yang, X.; Ma, C.; Yan, S.; Liu, Y.; He, Y.; Gou, Z. Systematical Evaluation of Mechanically Strong 3D Printed Diluted Magnesium Doping Wollastonite Scaffolds on Osteogenic Capacity in Rabbit Calvarial Defects. Sci. Rep. 2016, 6, 34029. [CrossRef]

205. Sa, M.-W.; Nguyen, B.-N.B.; Moriarty, R.A.; Kamalitdinov, T.; Fisher, J.P.; Kim, J.Y. Fabrication and Evaluation of 3D Printed BCP Scaffolds Reinforced with ZrO2 for Bone Tissue Applications. Biotechnol. Bioeng. 2018, 115, 989-999. [CrossRef]

206. Asadi-Eydivand, M.; Solati-Hashjin, M.; Shafiei, S.S.; Mohammadi, S.; Hafezi, M.; Abu Osman, N.A. Structure, Properties, and In Vitro Behavior of Heat-Treated Calcium Sulfate Scaffolds Fabricated by 3D Printing. PLoS ONE 2016, 11. [CrossRef]

207. Chang, C.-H.; Lin, C.-Y.; Liu, F.-H.; Chen, M.H.-C.; Lin, C.-P.; Ho, H.-N.; Liao, Y.-S. 3D Printing Bioceramic Porous Scaffolds with Good Mechanical Property and Cell Affinity. PLoS ONE 2015, 10, e0143713. [CrossRef]

208. Komlev, V.S.; Popov, V.K.; Mironov, A.V.; Fedotov, A.Y.; Teterina, A.Y.; Smirnov, I.V.; Bozo, I.Y.; Rybko, V.A.; Deev, R.V. 3D Printing of Octacalcium Phosphate Bone Substitutes. Front. Bioeng. Biotechnol. 2015, 3. [CrossRef]

209. Wang, W.; Caetano, G.; Ambler, W.S.; Blaker, J.J.; Frade, M.A.; Mandal, P.; Diver, C.; Bártolo, P. Enhancing the Hydrophilicity and Cell Attachment of 3D Printed PCL/Graphene Scaffolds for Bone Tissue Engineering. Materials 2016, 9, 992. [CrossRef]

210. Kim, J.A.; Kim, H.N.; Im, S.-K.; Chung, S.; Kang, J.Y.; Choi, N. Collagen-Based Brain Microvasculature Model in Vitro Using Three-Dimensional Printed Template. Biomicrofluidics 2015, 9, 024115. [CrossRef]

211. Hu, Y.; Wu, Y.; Gou, Z.; Tao, J.; Zhang, J.; Liu, Q.; Kang, T.; Jiang, S.; Huang, S.; He, J.; et al. 3D-Engineering of Cellularized Conduits for Peripheral Nerve Regeneration. Sci. Rep. 2016, 6, 32184. [CrossRef]

212. Lorber, B.; Hsiao, W.-K.; Martin, K.R. Three-Dimensional Printing of the Retina. Curr. Opin. Ophthalmol. 2016, $27,262-267$. [CrossRef]

213. Isaacson, A.; Swioklo, S.; Connon, C.J. 3D Bioprinting of a Corneal Stroma Equivalent. Exp. Eye Res. 2018, 173, 188-193. [CrossRef] [PubMed]

214. Mannoor, M.S.; Jiang, Z.; James, T.; Kong, Y.L.; Malatesta, K.A.; Soboyejo, W.O.; Verma, N.; Gracias, D.H.; McAlpine, M.C. 3D Printed Bionic Ears. Nano Lett. 2013, 13, 2634-2639. [CrossRef] [PubMed] 
215. Lee, J.-S.; Hong, J.M.; Jung, J.W.; Shim, J.-H.; Oh, J.-H.; Cho, D.-W. 3D Printing of Composite Tissue with Complex Shape Applied to Ear Regeneration. Biofabrication 2014, 6, 024103. [CrossRef] [PubMed]

216. Pati, F.; Shim, J.-H.; Lee, J.-S.; Cho, D.-W. 3D Printing of Cell-Laden Constructs for Heterogeneous Tissue Regeneration. Manuf. Lett. 2013, 1, 49-53. [CrossRef]

217. Lawlor, K.T.; Vanslambrouck, J.M.; Higgins, J.W.; Chambon, A.; Bishard, K.; Arndt, D.; Er, P.X.; Wilson, S.B.; Howden, S.E.; Tan, K.S.; et al. Cellular Extrusion Bioprinting Improves Kidney Organoid Reproducibility and Conformation. Nat. Mater. 2021, 20, 260-271. [CrossRef]

218. Lee, K.; Silva, E.A.; Mooney, D.J. Growth Factor Delivery-Based Tissue Engineering: General Approaches and a Review of Recent Developments. J. R. Soc. Interface 2011, 8, 153-170. [CrossRef]

219. Derr, K.; Zou, J.; Luo, K.; Song, M.J.; Sittampalam, G.S.; Zhou, C.; Michael, S.; Ferrer, M.; Derr, P. Fully Three-Dimensional Bioprinted Skin Equivalent Constructs with Validated Morphology and Barrier Function. Tissue Eng. Part C Methods 2019, 25, 334-343. [CrossRef]

220. Augustine, R.; Kalva, S.N.; Ahmad, R.; Zahid, A.A.; Hasan, S.; Nayeem, A.; McClements, L.; Hasan, A. 3D Bioprinted Cancer Models: Revolutionizing Personalized Cancer Therapy. Transl. Oncol. 2021, 14, 101015. [CrossRef]

221. Albritton, J.L.; Miller, J.S. 3D Bioprinting: Improving in Vitro Models of Metastasis with Heterogeneous Tumor Microenvironments. Dis. Model. Mech. 2017, 10, 3-14. [CrossRef]

222. Datta, P.; Dey, M.; Ataie, Z.; Unutmaz, D.; Ozbolat, I.T. 3D Bioprinting for Reconstituting the Cancer Microenvironment. NPJ Precis. Oncol. 2020, 4, 1-13. [CrossRef]

223. Murphy, S.V.; Atala, A. 3D bioprinting of tissues and organs. Nat. Biotechnol. 2014, 32, 773-785. [CrossRef]

224. Kankala, R.K.; Xu, X.M.; Liu, C.G.; Chen, A.Z.; Wang, S.B. 3D-Printing of Microfibrous Porous Scaffolds Based on Hybrid Approaches for Bone Tissue Engineering. Polymers 2018, 10, 807. [CrossRef]

225. Neufurth, M.; Wang, X.; Wang, S.; Steffen, R.; Ackermann, M.; Haep, N.D.; Müller, W.E. 3D printing of hybrid biomaterials for bone tissue engineering: Calcium-polyphosphate microparticles encapsulated by polycaprolactone. Acta Biomater. 2017, 64, 377-388. [CrossRef]

226. Oladapo, B.I.; Zahedi, S.A.; Adeoye, A.O.M. 3D printing of bone scaffolds with hybrid biomaterials. Compos. Part B Eng. 2019, 158, 428-436. [CrossRef]

227. Bahcecioglu, G.; Hasirci, N.; Bilgen, B.; Hasirci, V. 3D printed PCL/hydrogel construct with zone-specific biochemical composition mimicking that of the meniscus. Biofabrication 2019, 11, 025002. [CrossRef]

228. Dávila, J.L.; Freitas, M.S.; Inforçatti Neto, P.; Silveira, Z.C.; Silva, J.V.L.; d'Ávila, M.A. Fabrication of PCL/ $\beta$-TCP scaffolds by 3D mini-screw extrusion printing. J. Appl. Polym. Sci. 2016, 133, 43031. [CrossRef]

229. Nyberg, E.; Rindone, A.; Dorafshar, A.; Grayson, W.L. Comparison of 3D-Printed Poly- $\varepsilon$-Caprolactone Scaffolds Functionalized with Tricalcium Phosphate, Hydroxyapatite, Bio-Oss, or Decellularized Bone Matrix. Tissue Eng. Part A 2017, 23, 503-514. [CrossRef]

230. Axpe, E.; Oyen, M.L. Applications of Alginate-Based Bioinks in 3D Bioprinting. Int. J. Mol. Sci. 2016, 17, 1976. [CrossRef] [PubMed]

231. Kilian, D.; Ahlfeld, T.; Akkineni, A.R.; Bernhardt, A.; Gelinsky, M.; Lode, A. 3D Bioprinting of osteochondral tissue substitutesin vitro-chondrogenesis in multi-layered mineralized constructs. Sci. Rep. 2020, 10, 1-17. [CrossRef] [PubMed]

232. Placone, J.K.; Mahadik, B.; Fisher, J.P. Addressing present pitfalls in $3 \mathrm{D}$ printing for tissue engineering to enhance future potential. APL Bioeng. 2020, 4, 010901. [CrossRef] [PubMed]

233. Raya-Rivera, A.; Esquiliano, D.R.; Yoo, J.J.; Lopez-Bayghen, E.; Soker, S.; Atala, A. Tissue-Engineered Autologous Urethras for Patients Who Need Reconstruction: An Observational Study. Lancet 2011, 377, 1175-1182. [CrossRef]

234. Raya-Rivera, A.M.; Esquiliano, D.; Fierro-Pastrana, R.; López-Bayghen, E.; Valencia, P.; Ordorica-Flores, R.; Soker, S.; Yoo, J.J.; Atala, A. Tissue-Engineered Autologous Vaginal Organs in Patients: A Pilot Cohort Study. Lancet 2014, 384, 329-336. [CrossRef]

235. Alshahrani, H.A. Review of $4 \mathrm{D}$ printing materials and reinforced composites: Behaviors, applications and challenges. J. Sci. Adv. Mater. Devices 2021, 6, 167-185. [CrossRef]

236. Tamay, D.G.; Dursun Usal, T.; Alagoz, A.S.; Yucel, D.; Hasirci, N.; Hasirci, V. 3D and 4D Printing of Polymers for Tissue Engineering Applications. Front. Bioeng. Biotechnol. 2019, 7, 164. [CrossRef] 